\title{
Caffeic acid phenethyl ester induced cell cycle arrest and growth inhibition in androgen-independent prostate cancer cells via regulation of Skp2, p53, p21 ${ }^{\text {Cip1 }}$ and p27 Kip1
}

\author{
Hui-Ping Linn ${ }^{1, *}$, Ching-Yu Lin ${ }^{2, *}$, Chieh Huo ${ }^{2,3, *}$, Ping-Hsuan Hsiao ${ }^{2,4, *}$, \\ Liang-Cheng $\mathrm{Su}^{2}$, Shih Sheng Jiang ${ }^{1}$, Tzu-Min Chan ${ }^{5,6}$, Chung-Ho Chang ${ }^{2}$, \\ Li-Tzong Chen ${ }^{1}$, Hsing-Jien Kung ${ }^{1,7}$, Horng-Dar Wang ${ }^{4}$, Chih-Pin Chuu ${ }^{2,8,9,10,11}$ \\ ${ }^{1}$ National Institute of Cancer Research, National Health Research Institutes, Miaoli, Taiwan, ROC \\ ${ }^{2}$ Institute of Cellular and System Medicine, National Health Research Institutes, Miaoli, Taiwan, ROC \\ ${ }^{3}$ Department of Life Sciences, National Central University, Taoyuan, Taiwan, ROC \\ ${ }^{4}$ Institute of Biotechnology, National Tsing Hua University, Hsinchu City, Taiwan, ROC \\ ${ }^{5}$ Department of Medical Education and Research, China Medical University Beigan Hospital, Yunlin, Taiwan, ROC \\ ${ }^{6}$ Department of Medical Education and Research, China Medical University-An Nan Hospital, Tainan, Taiwan, ROC \\ ${ }^{7}$ Institute of Molecular and Genomic Medicine, National Health Research Institutes, Miaoli County, Taiwan, ROC \\ ${ }^{8}$ Graduate Institute of Basic Medical Science, China Medical University, Taichung, Taiwan, ROC \\ ${ }^{9}$ Graduate Program for Aging, China Medical University, Taichung, Taiwan, ROC \\ ${ }^{10}$ Biotechnology Center, National Chung Hsing University, Taichung, Taiwan, ROC \\ ${ }^{11}$ Ph.D. Program in Environmental and Occupational Medicine, Kaohsiung Medical University, Kaohsiung City, Taiwan, ROC \\ *These authors have contributed equally to this work \\ Correspondence to: \\ Chih-Pin Chuu, e-mail: cpchuu@nhri.org.tw \\ Keywords: Prostate cancer, caffeic acid phenethyl ester, cell cycle arrest, Skp2, p53 \\ Received: September 18, $2014 \quad$ Accepted: January 30, $2015 \quad$ Published: February 16, 2015
}

\section{ABSTRACT}

Prostate cancer ( $\mathrm{PCa}$ ) patients receiving the androgen ablation therapy ultimately develop recurrent castration-resistant prostate cancer (CRPC) within 1-3 years. Treatment with caffeic acid phenethyl ester (CAPE) suppressed cell survival and proliferation via induction of G1 or G2/M cell cycle arrest in LNCaP 104-R1, DU-145, 22Rv1, and C4-2 CRPC cells. CAPE treatment also inhibited soft agar colony formation and retarded nude mice xenograft growth of LNCaP 104-R1 cells. We identified that CAPE treatment significantly reduced protein abundance of Skp2, Cdk2, Cdk4, Cdk7, Rb, phospho-Rb S807/811, cyclin A, cyclin D1, cyclin H, E2F1, C-Myc, SGK, phosphop70S6kinase T421/S424, phospho-mTOR Ser2481, phospho-GSK3a Ser21, but induced p21 ${ }^{\text {cip1 }}$, p27 ${ }^{\text {kip1 }}$, ATF4, cyclin E, p53, TRIB3, phospho-p53 (Ser6, Ser33, Ser46, Ser392), phospho-p38 MAPK Thr180/Tyr182, Chk1, Chk2, phospho-ATM S1981, phospho-ATR S428, and phospho-p90RSK Ser380. CAPE treatment decreased Skp2 and Akt1 protein expression in LNCaP 104-R1 tumors as compared to control group. Overexpression of Skp2, or siRNA knockdown of p21 ${ }^{\mathrm{Cip} 1}, \mathrm{p} 27^{\mathrm{Kip} 1}$, or p53 blocked suppressive effect of CAPE treatment. Co-treatment of CAPE with PI3K inhibitor LY294002 or Bcl-2 inhibitor ABT737 showed synergistic suppressive effects. Our finding suggested that CAPE treatment induced cell cycle arrest and growth inhibition in CRPC cells via regulation of Skp2, p53, p21 ${ }^{\mathrm{cip} 1}$, and p27 ${ }^{\mathrm{Kip} 1}$. 


\section{INTRODUCTION}

Prostate cancer is the second most frequently diagnosed cancer of men and the fifth most common cancer overall in the world. Incidence of prostate cancer (PCa) is increasing steadily in almost all countries [1]. According to the statistics of Surveillance Epidemiology and End Results (SEER) of National Cancer Institute, more than 240,000 men were diagnosed with and more than 28,000 men died of cancer of the prostate in 2012 in United States. While surgery is often successful for organconfined $\mathrm{PCa}$, androgen ablation therapy is the primary treatment for metastatic PCa. However, most PCa patients receiving the androgen ablation therapy will ultimately develop castration-resistant prostate cancer (CRPC) within 1-3 years with a median overall survival time of $1-2$ years after relapse $[2,3]$. Currently, there is no effective standard therapy for CRPC. Although chemotherapy is usually applied for treatment of CRPC [4], these drugs show little effect on prolonging survival [4]. Undesired side effects of these chemotherapeutic agents include toxic deaths, strokes, thrombosis, neutropenia, edema, dyspnea, malaise, and fatigue [4]. Alternative therapies are therefore in need for CRPC.

Androgen receptor (AR), an androgen-activated transcription factor, belongs to the nuclear receptor superfamily. AR plays essential roles in the development of male sex organs and prostate tissues, maturation of bones, and normal female fertility. AR signaling is important for the development, progression, and metastasis of $\mathrm{PCa}$ [5]. Increase in AR mRNA and protein was observed in CRPC tumors compared to the primary prostate tumors [6-11]. $\mathrm{LNCaP}$ is a commonly used cell line established from a human lymph node metastatic lesion of prostatic adenocarcinoma [12], which expresses AR and prostate specific antigen (PSA). We have established LNCaP sublines mimic the progression of PCa. An androgen-dependent clonal subline of the LNCaP human prostate cancer cell line called LNCaP 104-S was subjected to long-term androgen deprivation in order to model changes which occur in the PCa cells in patient undergoing androgen-ablation therapy. $\mathrm{LNCaP}$ 104-S cells first underwent a G1 cell cycle arrest and subsequently died $[13,14]$. However, a small portion of the cells survived and re-started to proliferate after about 40 passages ( half year) in androgen-depleted medium. The surviving LNCaP 104-S cells gave rise to LNCaP 104$\mathrm{R} 1$ cells $[13,14]$. Proliferation of LNCaP 104-R1 cells is androgen-independent but is repressed by physiological concentration of androgens [13, 14]. During the transition of LNCaP 104-S cells to LNCaP 104-R1, AR mRNA and protein level increased dramatically. AR transcriptional activity also increased by 20 -fold during the progression $[13,14]$. Our LNCaP prostate cancer progression model mimics the clinical situations in which AR-positive prostate tumors recur following androgen deprivation [2, $15,16]$.

Caffeic acid phenethyl ester (CAPE) is a main bioactive component extracted from honeybee hive propolis. CAPE is a well known NF- $\kappa \mathrm{B}$ inhibitor at concentrations of $50 \mu \mathrm{M}$ to $80 \mu \mathrm{M}$ by preventing the translocation of p65 unit of NF- $\mathrm{KB}$ and the binding between NF- $\kappa B$ and DNA [17]. We previously reported that CAPE dosage dependently suppressed the proliferation of androgen-dependent LNCaP 104-S and AR-negative PC-3 cells $[18,19]$. Administration of CAPE by gavage significantly inhibited the tumor growth of LNCaP and PC-3 xenografts in nude mice [18-20]. We discovered that CAPE treatment inhibited cell growth and induced G1 cell cycle arrest by suppressing c-Myc and Akt-related protein signaling networks in LNCaP 104-S and PC-3 cells [18-20]. However, the protein expression profile and response to treatment of chemotherapy drugs or kinase inhibitors was quite different between LNCaP 104R1 and LNCaP 104-S cells [21]. We therefore used LNCaP 104-R1 cells as well as other CRPC cell lines 22Rv1, DU-145, and LNCaP C4-2 to determine the molecular mechanisms lying underneath of the anticancer effects of CAPE on CRPC cells. Micro-Western Array (MWA) is an antibody-based modified reverse phase array allows detecting protein expression level or phosphorylation status change of 96-384 different antibodies in 6-15 samples simultaneously [22]. We used MWA to determine the changes of signaling protein profile in LNCaP 104R1 cells being treated with CAPE. Our study suggested that CAPE treatment can efficiently induced G1 or G2/M cell cycle arrest, cellular and growth inhibition in CRPC cells via inhibition of Skp2 as well as induction of $\mathrm{p} 21^{\mathrm{Cip} 1}$, p2 $7^{\text {Kip1 }}$, and p53 in CRPC cell lines. Our finding implied that CAPE treatment might be a potential therapy for patients with CRPC.

\section{RESULTS}

\section{CAPE treatment suppressed the proliferation and survival of castration-resistant prostate cancer (CRPC) cell lines}

Treatment of CAPE (dissolved in ethanol) at 10$40 \mu \mathrm{M}$ for $96 \mathrm{~h}$ significantly reduced the cell number of AR-rich androgen-independent LNCaP 104-R1 cells dose-dependently as determined by light microscopy (Supplementary Figure 1). The ethanol control did not affect cell number of LNCaP 104-R1 cells as compared to no treatment (data not shown). Examination using fluorescent microscopy with Hoechst dye staining and DAPI staining indicated that cell survival and proliferation of commonly used CRPC cell lines, including LNCaP 104R1 (Figure 1), AR-positive 22Rv1 (Supplementary Figure 2), AR-negative DU-145 (Supplementary Figure 3), and 

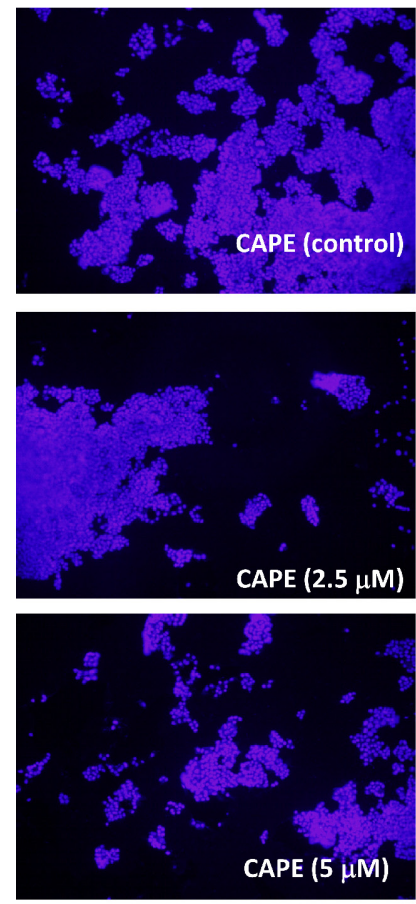

DAPI staining
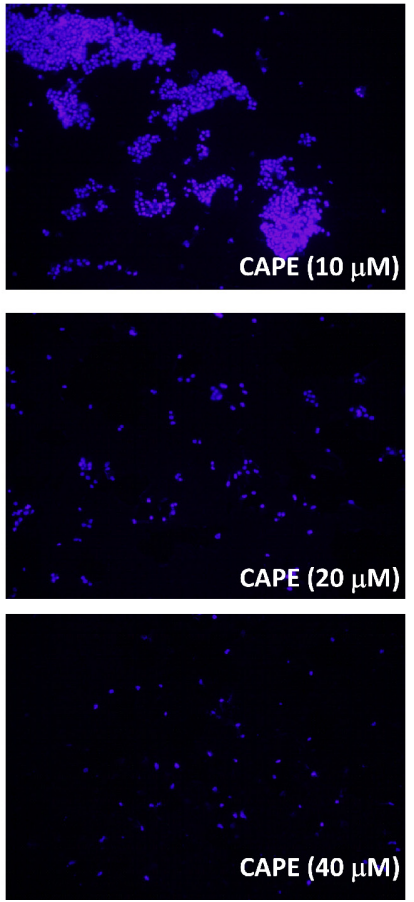

Hoechst staining
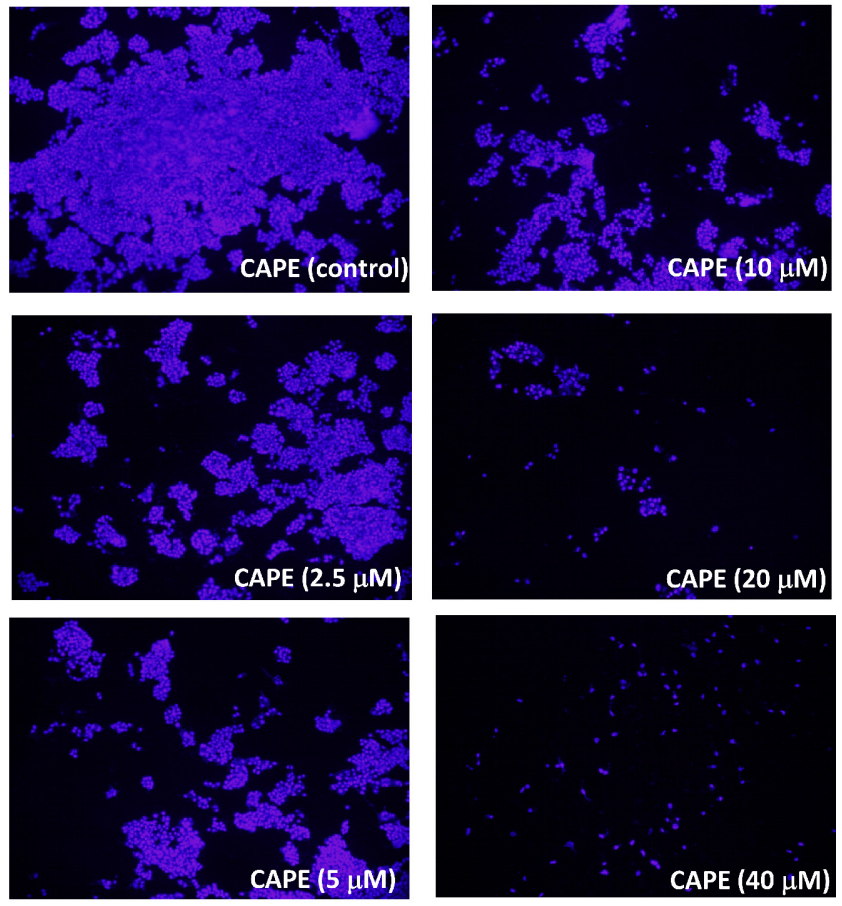
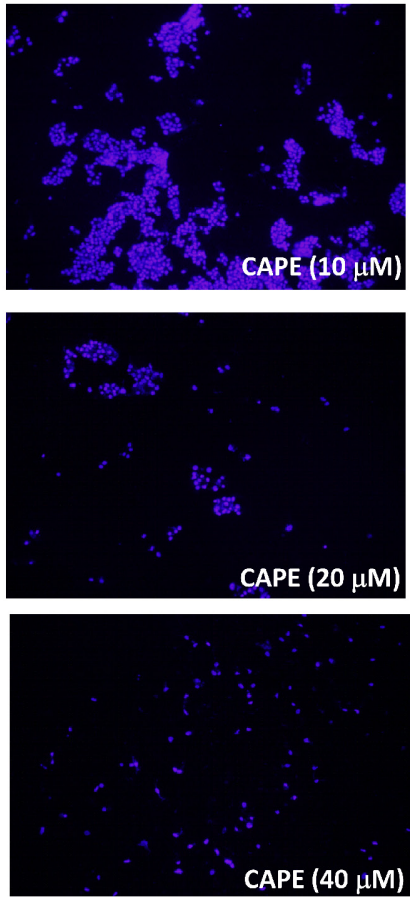

Figure 1: CAPE treatment for $96 \mathrm{~h}$ reduced cell proliferation of LNCaP 104-R1 cells. DAPI staining and Hoechst dyestaining of LNCaP 104-R1 cells being treated with increasing concentrations of CAPE for $96 \mathrm{~h}$ was used to monitor cell proliferation of LNCaP 104-R1 cells using fluorescent microscope with magnification of 100X.

AR-positive LNCaP C4-2 cells (Supplementary Figure 4) were all significantly suppressed by CAPE treatment dosedependently. The suppressive effects of CAPE on survival of CRPC cells were further confirmed by MTT assay and Hoechst 33258 96-well proliferation assay. MTT assay and Hoechst 33258 proliferation assay indicated an $\mathrm{IC}_{50}$ of $16.5 \mu \mathrm{M}$ and $18.9 \mu \mathrm{M}$, respectively, for CAPE to cause growth inhibition on LNCaP 104-R1 cells (Figure 2A). The growth inhibitory effect of CAPE was evident within 24 hours of treatment but the suppressive effect accumulated over time (Figure $2 \mathrm{~B}$ ). The $\mathrm{IC}_{50}$ of 24,48 , 72 , and $96 \mathrm{~h} \mathrm{CAPE}$ treatment on LNCaP 104-R1 cells was $64.0,30.5,20.5$, and $18.0 \mu \mathrm{M}$, respectively. We compared the sensitivity of LNCaP 104-R1 cells to CAPE treatment with the four other CRPC cell lines. CAPE treatment dosage-dependently suppressed the proliferation of LNCaP 104-R1, LNCaP C4-2, 22Rv1, PC-3, and DU-145 cells (Figure 2C) with an $\mathrm{IC}_{50}$ of 18.9, 10.9, 19.1, 23.2, and $22.6 \mu \mathrm{M}$, respectively. CAPE treatment caused the CRPC cells to proliferate slower. The doubling time of $\mathrm{LNCaP}$ 104-R1, LNCaP C4-2, 22Rv1, and DU-145 is 30.7, 37.4, 37.4 , and $36.0 \mathrm{~h}$, respectively. Under the treatment of $10 \mu \mathrm{M}$ CAPE, the doubling time of these cells increased to $47.5,75.8,106.8$, and $40.5 \mathrm{~h}$, respectively. When being treated with $20 \mu \mathrm{M}$ CAPE, the doubling time of LNCaP 104-R1 and DU-145 further extended to 68.6 and 44.2 $\mathrm{h}$, respectively. We did not examine the doubling time of LNCaP C4-2 and 22Rv1 under treatment of $20 \mu \mathrm{M} \mathrm{CAPE}$, as they proliferated too slow under this condition. Colony formation assay revealed that treatment with $10 \mu \mathrm{M}$ CAPE reduced colony formation of LNCaP 104-R1 cells by $90 \%$ while treatment with $20 \mu \mathrm{M}$ CAPE completely blocked the formation of LNCaP 104-R1 colonies (Figure 2D). These results confirmed the anti-cancer effect of CAPE against CRPC cells.

\section{CAPE treatment induced G1 or G2 cell cycle arrest in CRPC cells}

Annexin $\mathrm{V}$ staining and TUNEL assay for LNCaP 104-R1, LNCaP C4-2, 22Rv1, and DU-145 cells did not reveal any increase of apoptotic cells under CAPE treatment (data not shown). Western blotting analysis illustrated that protein expression of LC3-II and Beclin was not altered by CAPE treatment (data not shown), implying that autophagy probably did not happen in these CRPC cells. Some of the LNCaP 104-R1 cells treated with CAPE showed moderate positive $\beta$-galactosidase staining (Supplementary Figure 5). However, the cell morphology did not enlarge, suggesting that CAPE possibly caused hypoxia-induced cell cycle arrest or quiescence in 104-R1 cells, but not cell senescence (Supplementary Figure 5) [23-25]. Flow cytometric analysis revealed a reduction of cells in the $\mathrm{S}$ phase and $\mathrm{G} 2 / \mathrm{M}$ phase but an increase of cells in the G1 phase population in LNCaP 104-R1 cells under CAPE treatment (Figure 3A), suggesting that CAPE caused G1 cell cycle arrest in LNCaP 104-R1 cells. On the other hand, CAPE treatment reduced G1 phase 
A
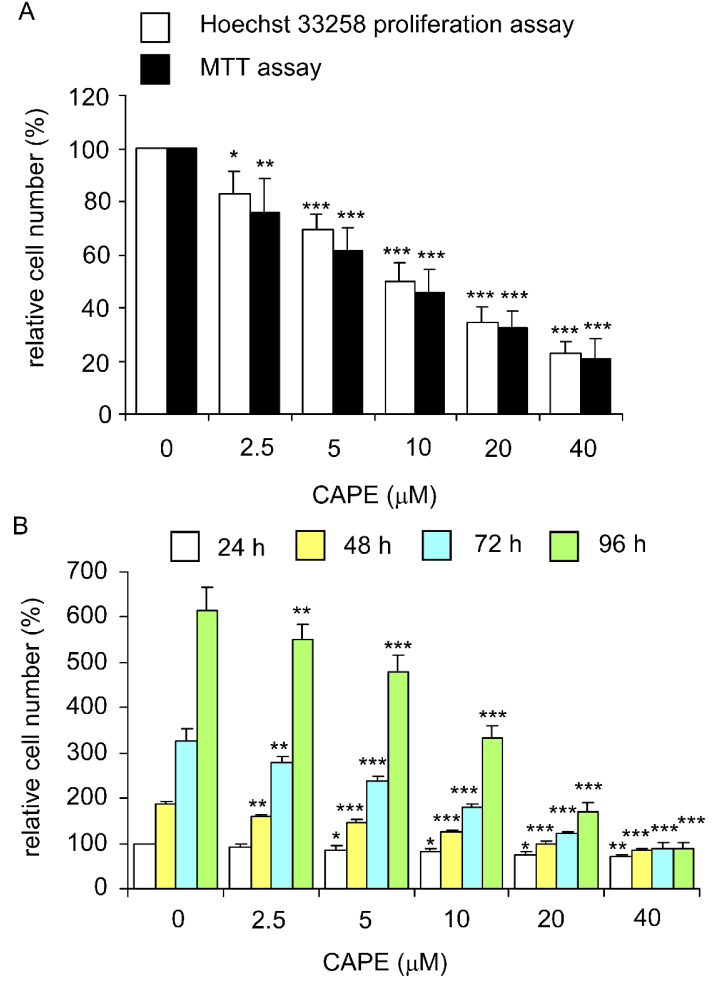

C

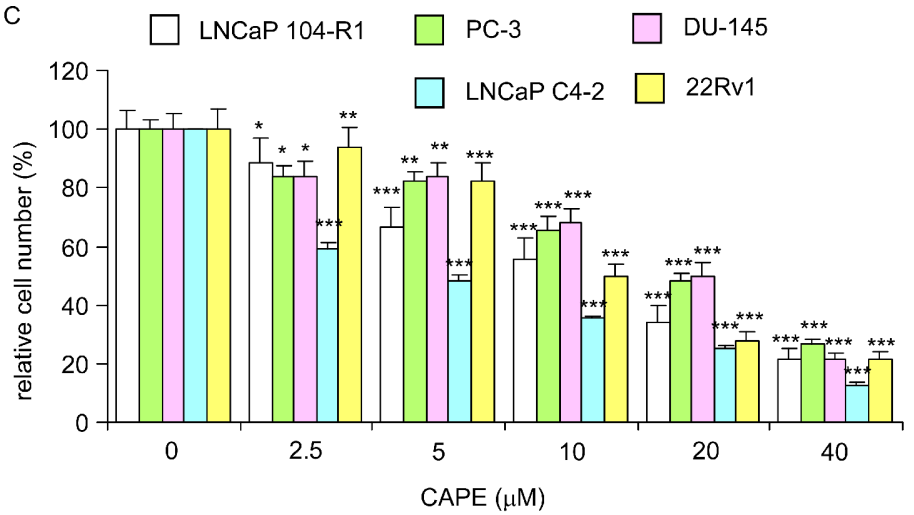

D
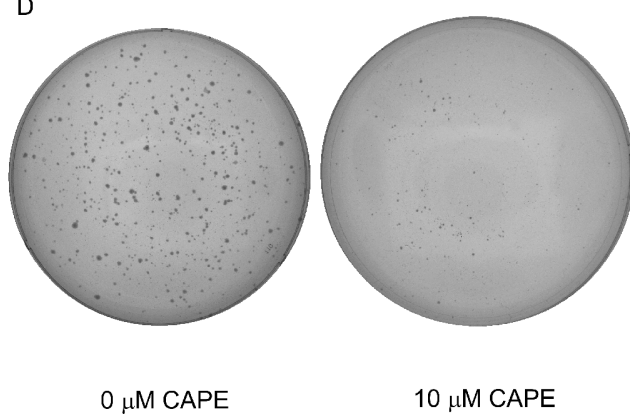

$10 \mu \mathrm{M}$ CAPE

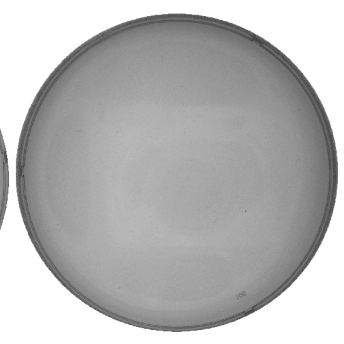

$20 \mu \mathrm{M}$ CAPE

Figure 2: CAPE treatment dose-dependently reduced cell survival, proliferation, and soft agar colony formation of CRPC cells. (A) LNCaP 104-R1 cells were treated with increasing concentrations of CAPE for $96 \mathrm{~h}$ to determine suppressive effect of CAPE on cell proliferation. Relative cell number was determined by either Hoechst 33258 fluorescence based-96 well proliferation assay or by MTT assay. Relative cell number was normalized to cell number of control (no treatment). (B) LNCaP 104-R1 cells were treated with increasing concentrations of CAPE for $24,48,72,96 \mathrm{~h}$ to investigate the suppressive effects of CAPE. Relative cell number was normalized to cell number of control (no treatment) at $24 \mathrm{~h}$ and was determined by Hoechst 33258 fluorescence based-96 well proliferation assay. (C) LNCaP 104-R1, PC-3, DU-145, LNCaP C4-2, and 22Rv1 cells were treated with increasing concentrations of CAPE for 96 h to investigate the suppressive effects of CAPE. Relative cell number determined by Hoechst 33258 fluorescence based-96 well proliferation assay and was normalized to cell number of control (no treatment) for individual cell line. Asterisks *, **, and *** represented statistical significance in cell number of $p<0.05, p<0.01$, and $p<0.001$, respectively, as compared to that of control. (D) Anticancer effect of CAPE was confirmed by the colony formation assay of LNCaP $104-\mathrm{R} 1$ cells treated with 0 , 10 , or $20 \mu \mathrm{M}$ CAPE for 14 days. Image is representative of three biological replicates.

population but increased $\mathrm{G} 2 / \mathrm{M}$ phase population in DU145 (Figure 3B), LNCaP C4-2 (Figure 3C), and 22Rv1 (Figure 3D) cells, indicating that CAPE caused G2/M cell cycle arrest in DU-145, C4-2, and 22Rv1 cells.

\section{CAPE treatment retarded the growth of LNCaP 104-R1 xenograft in nude mice}

Administration of CAPE by gavage $(10 \mathrm{mg} / \mathrm{kg}$ body weight per day) for eight weeks resulted in $50 \%$ reduction of tumor volume (Figure $4 \mathrm{~A}$ ), suggesting that CAPE treatment retarded the growth of LNCaP 104R1 xenografts. CAPE treatment did not affect the body weight of the mice (data not shown), which means that the dosage used was not overtly toxic. CAPE gavage slowed down the tumor growth of LNCaP 104-R1 cells, which was consistent with our observation that CAPE treatment induced cell cycle arrest but not apoptosis. Western blotting assay indicated that CAPE treatment reduced protein expression of Skp2 and Akt1 in 104-R1 xenografts as compared to the control group (Figure 4B, 4C). Although there was a trend that CAPE increased p53 and p $27^{\text {Kip } 1}$ but decreased cyclin D1 in tumors, the difference in protein abundance between control and treatment group was not statistically significant (Figure 4C).

\section{CAPE treatment affected the expression of proteins regulating cell survival, cell proliferation, cell cycle regulation, DNA damage checkpoint, and PI3K-Akt signaling pathway}

As CAPE treatment reduced cell proliferation and induced cell cycle arrest in CRPC cells, we used Micro-Western Arrays (MWAs), a high-throughput Western blotting assay [19, 22, 26], to determine how proteins regulating cell proliferation, cell survival, and cell cycle progression are affected by CAPE treatment. CAPE treatment significantly decreased protein levels of fatty acid synthase (FAS), retinoblastoma protein (Rb), phospho-Rb Ser807/811, c-Myc, p70S6kinase, 

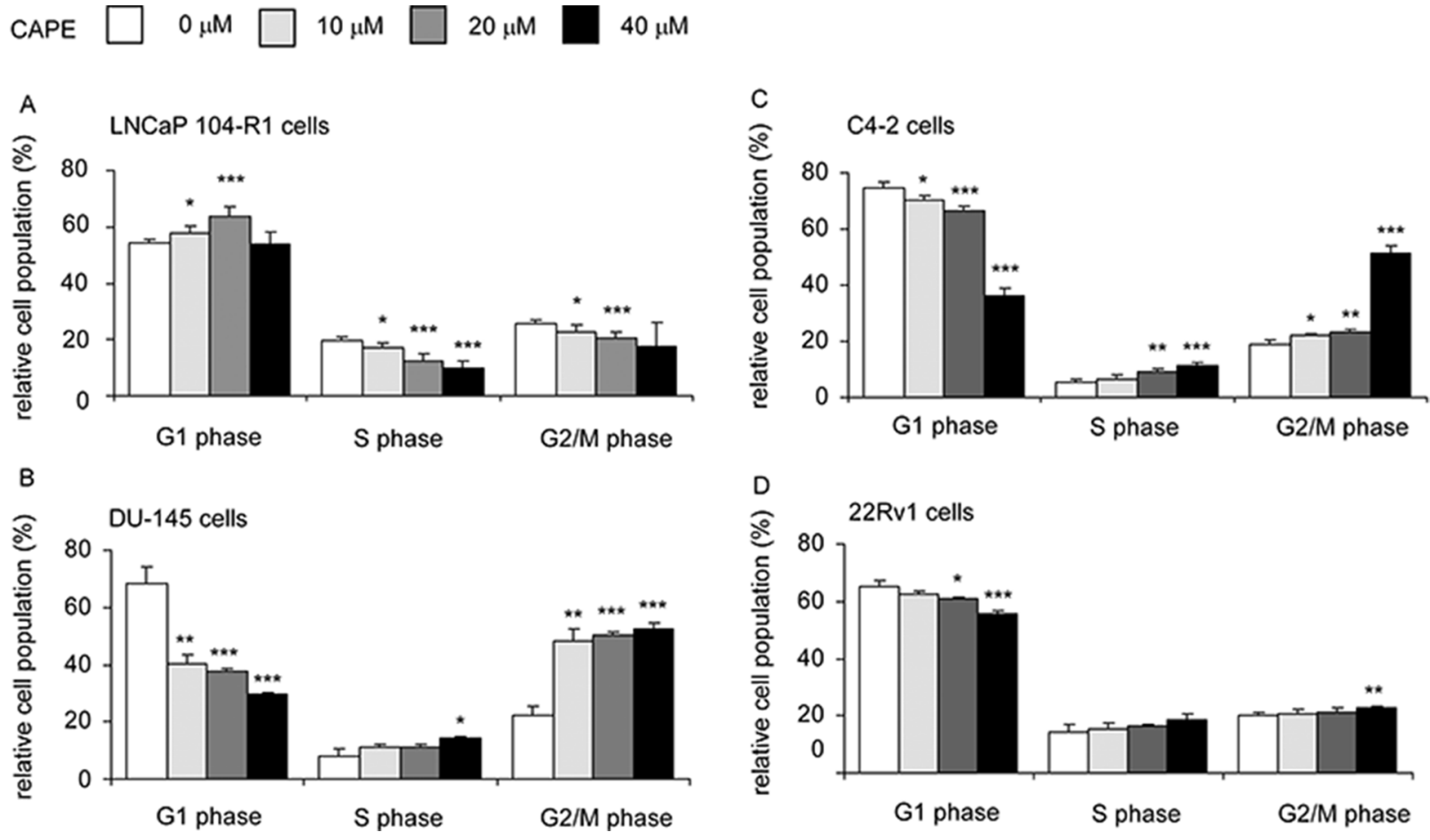

Figure 3: CAPE treatment induced G1 or G2/M cell cycle arrest in CRPC cells. LNCaP 104-R1 (A), DU-145 (B), LNCaP C4-2 (C), and 22Rv1 (D) cells were treated with 0, 10, 20, or $40 \mu \mathrm{M}$ CAPE for $96 \mathrm{~h}$, harvested, and stained with propidium iodide dye for flow cytometric analysis of cell cycle distribution. Asterisk* and *** represents statistically significant difference $p<0.05$ and $p<0.001$, respectively, between the two group of cells being compared.

phospho-p70S6kinase Thr421/Ser424, Skp2, p90RSK, and $\mathrm{NF}-\kappa \mathrm{B}$ p65. Alternatively, CAPE treatment significantly increased p53, phospho-p53 Ser392, phospho-p53 Ser33, phospho-p53 S6, phospho-p53 Ser46, p27 ${ }^{\text {Kip1 }}$, mTOR, CK1, GSK $3 \alpha$, CK2 $\alpha$, cyclin A, p38 MAPK, and p21 $1^{\mathrm{Cip} 1}$ (Figure 5A, 5B).

Conventional Western blotting assay was then used to confirm the changes of protein expression. CAPE treatment affected proteins regulating cell cycle, proliferation, survival, DNA damage check point, and PI3K-Akt signaling pathway. Expression of Cdk2, phospho-Cdk2 Thr160, Cdk4, Cdk7, Skp2, c-Myc, Rb, phospho-Rb Ser807/811, cyclin A, cyclin D1, cyclin H, and $\mathrm{E} 2 \mathrm{~F} 1$ proteins was significantly suppressed by CAPE treatment (Figure 6A, 6B), while protein abundance of cyclin E, p27 ${ }^{\text {Kip1 } 1}$, p2 $1^{\text {Cip1 }}$, p53, phospho-p53 Ser392, phospho-p53 Ser33, phospho-p53 S6, phospho-p53 Ser46, CHK1, CHK2, phospho-ATM Ser1981, phospho-ATR Ser428, and ATF4 (Figure 6A, 6B) were significantly induced by CAPE treatment.

The protein abundance of total Akt, Akt1, Akt2, and phospho-Akt Ser473 was decreased by CAPE treatment (Figure 7A, 7B). Additionally, CAPE treatment suppressed the protein expression of PDK1, SGK, phospho-SGK S255/T256, FAS, p70S6kinase, phospho-p70S6kinase Thr421/Ser424, mTOR, phospho-mTOR Ser2481, and phospho-GSK3 $\alpha$ Ser21 (Figure 7A, 7B). Conversely, CAPE treatment increased phospho-CREB Ser133, phospho-p38 MAPK Thr180/Tyr182, and phosphop90RSK Ser380, Bax, CKII $\alpha$, and TRIB3.

Skp2, p21 $1^{\text {Cip1 }}, \mathrm{p} 27^{\text {Kip1 }}$, and p53 are proteins important in regulating cell proliferation and cell cycle progression, while Chk1, Chk2, ATM, and ATR are DNA damage checkpoint proteins. Expression of these proteins was significantly affected by CAPE treatment in LNCaP 104R1 cells (Figures 5-7). We therefore examined if CAPE treatment also affected expression of these proteins in 22Rv1, LNCaP C4-2, and DU-145 cells. Similar to LNCaP 104-R1 cells, Skp2 protein abundance in 22Rv1, C4-2, and DU-145 cells was significantly suppressed by CAPE treatment (Figure 8, Figure 9). On the other hand, CAPE treatment induced expression of $\mathrm{p} 21^{\text {Cip1 }}, \mathrm{p} 27^{\mathrm{Kip} 1}$, p53, Chk1, Chk2, phospho-ATM Ser1981, and phosphoATR Ser428 in all four CRPC cell lines (Figures 8, 9). The changes of these proteins may all contribute to the inhibition of cell growth as well as induction of cell cycle arrest in CRPC cells.

\section{Overexpression of Skp2 rescued the suppressive effect of CAPE on cell proliferation of 104-R1 cells}

CAPE treatment caused $49 \%, 55 \%$, and $65 \%$ reduction of Skp2, c-Myc, and total Akt, respectively. To determine if CAPE suppressed cell proliferation through suppression of Skp2, c-Myc, or Akt, we overexpressed 

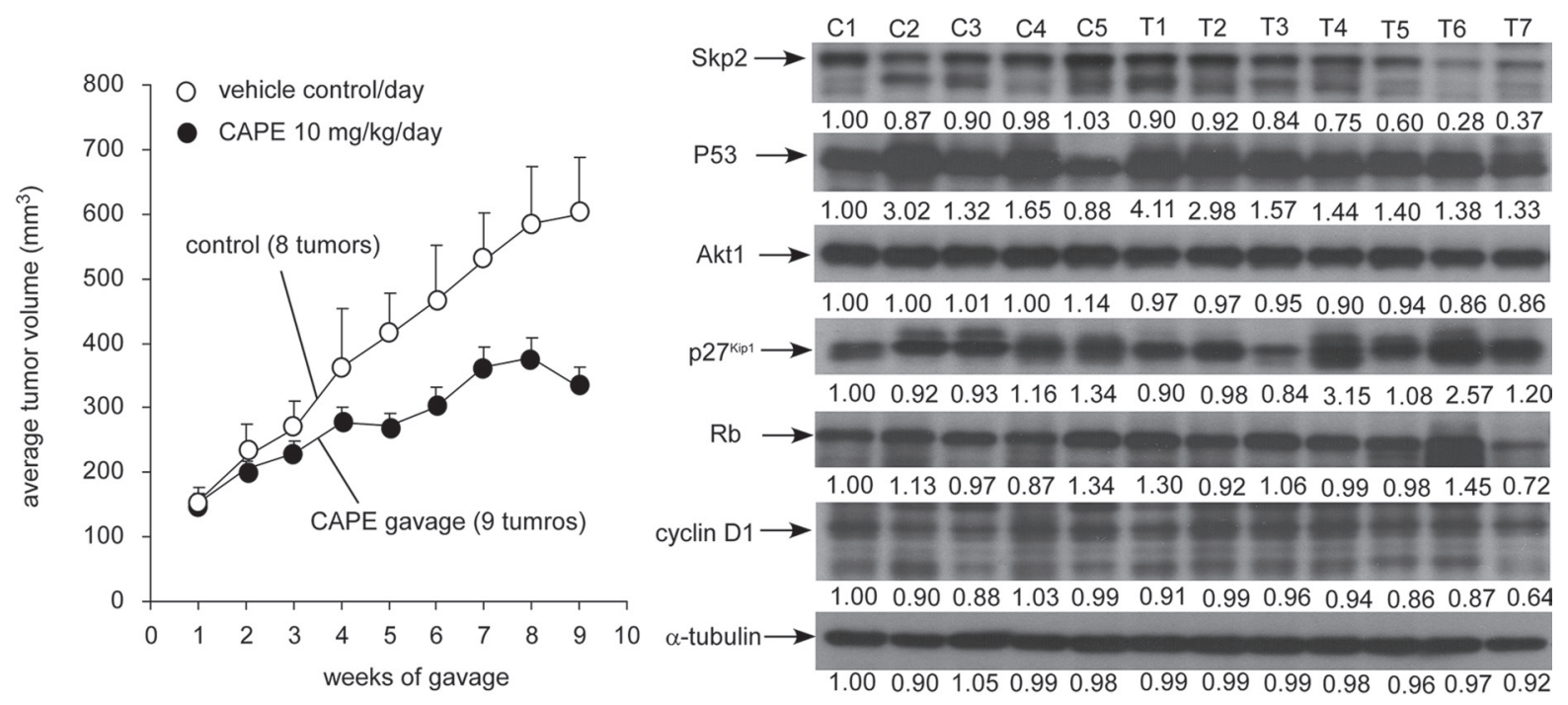

$\mathrm{C}$

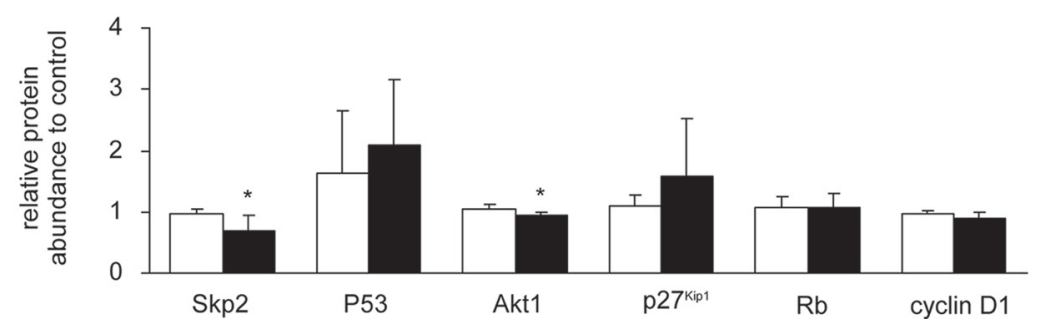

Figure 4: CAPE suppressed tumor growth of LNCaP 104-R1 xenografts. (A) LNCaP 104-R1 cells were injected subcutaneously into athymic mice to form tumors. After 14 weeks, the average tumor volume exceeded $150 \mathrm{~mm}^{3}$. The mice were then separated into control group and CAPE treatment group. Control group contained 6 mice and 8 tumors, while CAPE treatment group contained 6 mice and 9 tumors. CAPE $(10 \mathrm{mg} / \mathrm{kg} /$ day in sesame oil) or vehicle (sesame oil) was administered by gavage starting from 14th week after cancer cell injection and was shown as 1st week for gavage in figure. Tumor volume and body weight of mice carrying 104-R1 xenografts were measured weekly. Tumor volume was shown as volume plus standard error (SE). Mice body weight in two groups did not show significant difference. (B) Protein expression of Skp2, p53, Akt1, p27 Kip1, cyclin D1, and Rb in LNCaP 104-R1 tumors from control group or CAPE treatment group was assayed with Western blotting assay. $\alpha$-tubulin was used as loading control. (C) The average expression level of Skp2, p53, Akt1, p27 Kipl, cyclin D1, and Rb proteins in CAPE-treated LNCaP 104-R1 tumors was compared to those in tumors from control group. Asterisk* represents statistically significant difference $p<0.05$ between the two groups.

Skp2, c-Myc, and Akt1 in LNCaP 104-R1 cells. Akt1 over-expression slightly blocked the anti-proliferative effect of CAPE (Figure 10A). Surprisingly, c-Myc over-expression did not show any rescue effect (data not shown). Overexpression of Skp2 in LNCaP 104R1 cells significantly blocked the suppressive effect of CAPE treatment (Figure 10B). Flow cytometry analysis indicated that CAPE treatment induced G1 cell cycle arrest in control LNCaP 104-R1 cells but not LNCaP 104-R1 cells overexpressing Skp2 (Figure 10C). CAPE treatment suppressed cyclin D1 and c-Myc in both control and Skp2 overexpressing LNCaP 104-R1 cells (Figure 10D). However, the accumulation of $\mathrm{p} 27^{\mathrm{Kip} 1}$ and $\mathrm{p} 21^{\mathrm{Cip} 1}$ was $22 \%$ and $50 \%$ less, respectively, while abundance of Cdk2 and phospho-Cdk2 Thr160 were either less or not affected by CAPE in Skp2 overexpressing LNCaP 104-R1 cells as compared to the control LNCaP 104-R1 cells. The lower endogenous level p2 $7^{\text {Kip1 }}$ in Skp2 overexpressing
LNCaP 104-R1 cells was consistent to the function of Skp2 as Skp2 target p27 $7^{\text {Kip1 }}$ for degradation. Consequently, reduction of Skp2, Cdk2, and phospho-Cdk2 Thr160, as well as accumulation of $\mathrm{p} 27^{\mathrm{Kipl}}$ and $\mathrm{p} 21^{\mathrm{Cip} 1}$ were likely to play essential roles in the G1 cell cycle arrest induced by CAPE treatment in LNCaP 104-R1 cells.

\section{Knockdown of $\mathrm{p} 27^{\mathrm{Kip} 1}, \mathrm{p} 21^{\mathrm{Cip} 1}$, or $\mathrm{p} 53$ rescued the suppressive effect of CAPE on cell proliferation of LNCaP 104-R1 cells}

Besides Skp2, CAPE treatment induced protein expression of $\mathrm{p} 27^{\mathrm{Kip} 1}, \mathrm{p} 21^{\text {Cip1 }}$, and $\mathrm{p} 53$ in all CRPC cell lines. We therefore determined if siRNA knockdown of p $27^{\text {Kipl }}$, p2 $1^{\text {Cip1 }}$, or p53 may rescue the growth inhibition of $\mathrm{LNCaP}$ 104-R1 cells induced by CAPE treatment. Indeed, siRNA knockdown of p27 $7^{\text {Kip1 }}$ (Figure 11A), p21 $1^{\text {Cip1 }}$ (Figure 11B), or p53 (Figure 11C) rescued the cell proliferation of $\mathrm{LNCaP}$ 


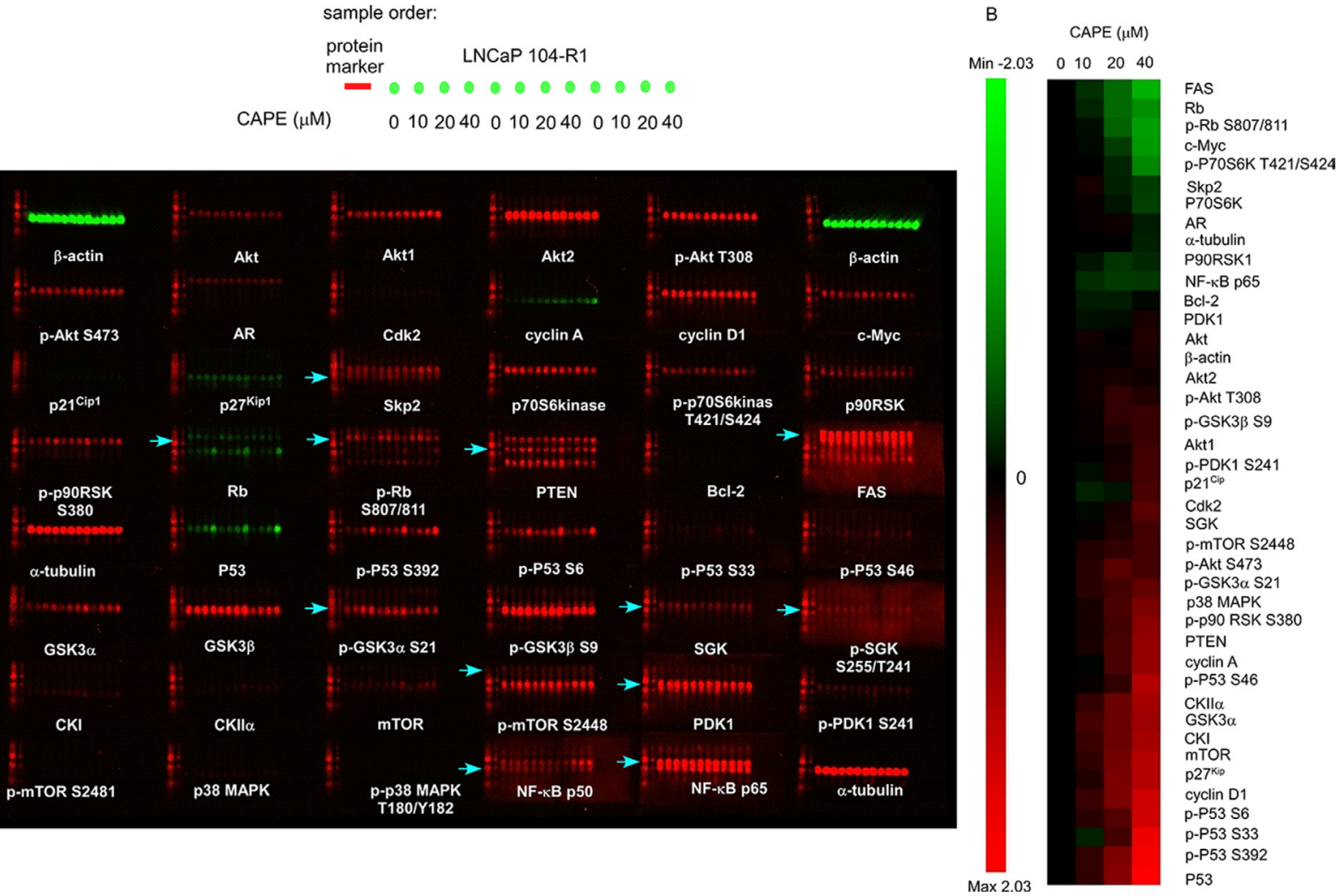

Figure 5: Micro-Western Array image and heatmap of abundance and phosphorylation fold changes of signaling proteins in LNCaP 104-R1 cells treated with CAPE. (A) LNCaP 104-R1 cells were treated with 0, 10, 20, $40 \mu \mathrm{M}$ CAPE for 96 h. Micro-Western Arrays were performed to measure the changes in abundance and modification of total Akt, Akt1, Akt2, phospho-Akt Thr308, phospho-Akt Ser473, AR, Cdk2, cyclin A, cyclin D1, c-Myc, p21 cip1 , p27 ${ }^{\text {kip1 }}$, Skp2, p70S6 kinase, phospho-p70 S6 kinase Thr421/ Ser424, p90RSK, phospho-p90RSK Ser380, Rb, phospho-Rb Ser807/811, PTEN, Bcl-2, fatty acid synthase (FAS), p53, phospho-p53 Ser392, phospho-p53 Ser6, phospho-p53 Ser33, phospho-p53 Ser46, GSK3 $\alpha$, GSK3 $\beta$, phospho-GSK3 $\alpha$ Ser21, phospho-Gsk3 $\beta$ Ser9, SGK, phospho-SGK Ser255/Thr241, CKI, CKII $\alpha$, mTOR, phospho-mTOR Ser2448, PDK1, phospho-PDK1 Ser241, phospho-mTOR ser2481,

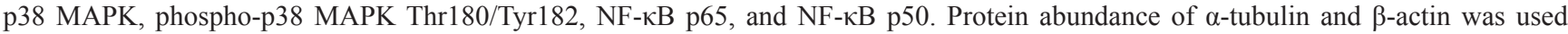
as loading control. Red color and green color indicated $680 \mathrm{nM}$ and $780 \mathrm{nM}$ wavelength detected by Licor Odyssey scanner for rabbit antibodies and mouse antibodies, respectively. Blue arrows indicated the correct location of band for the detected proteins. (B) Proteins were organized in the $y$-axis of the heatmap based on time of maximal fold change amplitude. Green color indicated decrease of protein expression while red color indicated increase of protein expression under treatment of CAPE.

104-R1 cells being treated with increasing concentration of CAPE, confirming their essential role in regulating cell cycle arrest induced by CAPE treatment.

\section{Co-treatment of CAPE with LY294002 or ABT737 suppressed proliferation of LNCaP 104-R1 cells}

Synergistic effect implies the suppressive effect of two drugs being treated together is greater than the sum of their separate suppressive effect at the same doses. Additive suppressive effect indicates that the combination of two drugs produces an effect that is greater than the effect of one of the drug. According to the fact that phosphorylation of Akt was only slightly suppressed by CAPE treatment and overexpression Akt1 only slightly rescued the suppressive effect of CAPE treatment in LNCaP 104-R1 cells, we hypothesized that co-treatment of CAPE with PI3K inhibitor LY294002 will show additive suppressive effect on cell growth of LNCaP 104$\mathrm{R} 1$ cells. Indeed, combination of 2.5-10 $\mu \mathrm{M}$ CAPE with 1-5 $\mu \mathrm{M}$ LY294002 showed synergetic suppression on cell growth of LNCaP 104-R1 cells (Figure 12A-12C). Combination of higher dose of CAPE $(20$ or $40 \mu \mathrm{M})$ with LY294002 only showed additive but not synergistic suppressive effects. Expression of Bcl-2 in androgenindependent $\mathrm{LNCaP} 104-\mathrm{R} 1$ cells is 65 -fold higher that in parental androgen-dependent LNCaP 104-S cells at culture condition [21]. Bcl-2 expression may protect LNCaP 104R1 cells from cell death under stress or drug treatment. CAPE treatment slightly decreased the protein level of Bcl-2 (Figure 7). We anticipated that co-treatment with Bcl-2 inhibitor ABT737 will exhibit additive suppressive effect. As shown in Figure 12D-12F, combined treatment of CAPE with ABT737 demonstrated additive suppressive effect while combination of low dose of ABT737 with CAPE displayed synergetic suppressive effect. 
A

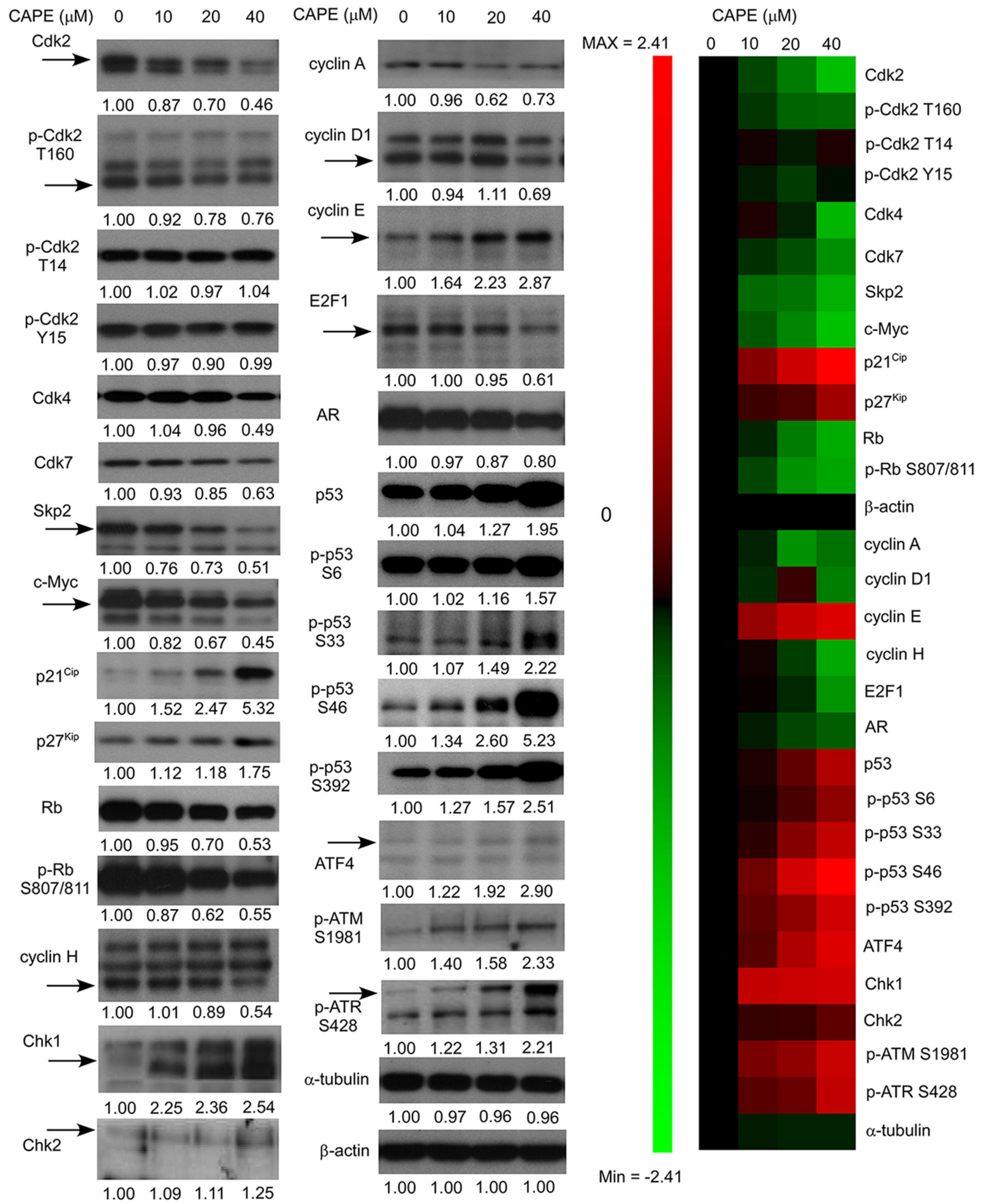

Figure 6: CAPE treatment affected abundance and phosphorylation of proteins regulating proliferation, cell cycle progression, and survival in LNCaP 104-R1 cells. (A) Protein expression of Cdk2, phospho-Cdk2 Thr160, phospho-Cdk2 Thr14, phospho-Cdk2 Tyr15, Cdk4, Cdk7, Skp2, c-Myc, p21 ${ }^{\text {Cip1 }}$, p27 ${ }^{\text {Kipl }}$, Rb, phospho-Rb Ser807/811, cyclin H, cyclin A, cyclin D1, cyclin E, E2F-1, AR, p53, phospho-p53 Ser6, phospho-p53 Ser33, and phospho-p53 Ser46, phospho-p53 Ser392, Chk1, Chk2, phospho-ATM S1981, phospho-ATR S428, and ATF4 in LNCaP 104-R1 cells treated with 0, 10, 20, and $40 \mu \mathrm{M}$ CAPE for 96 h were assayed by Western blotting. Protein abundance of $\alpha$-tubulin and $\beta$-actin was used as loading control. (B) Proteins expression level was organized in the y-axis of the heatmap based on time of maximal fold change amplitude. Green color indicated decrease of protein expression while red color indicated increase of protein expression under treatment of CAPE. 


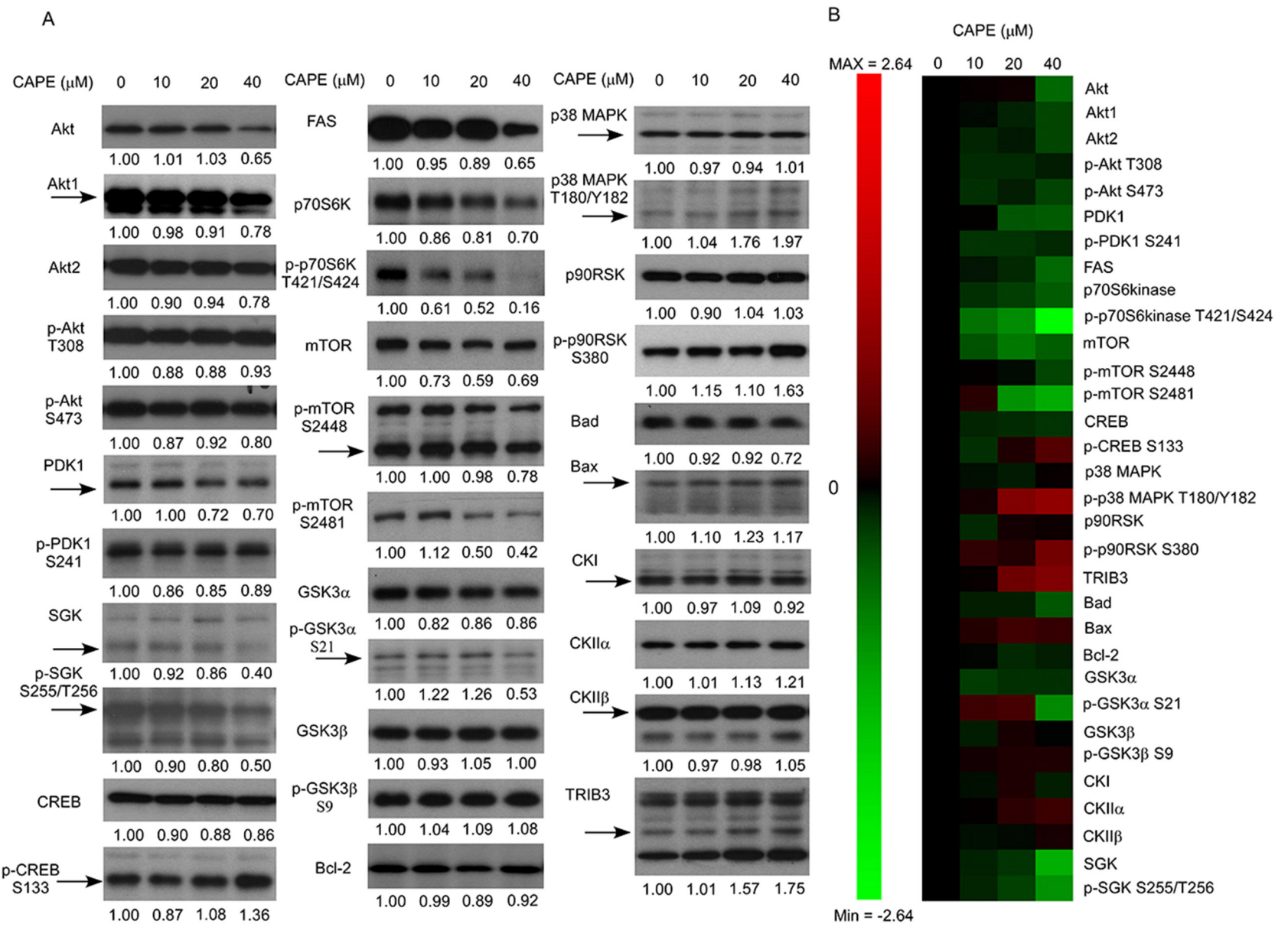

Figure 7: CAPE treatment affected abundance and phosphorylation of proteins involved in PI3K-Akt signaling pathways. (A) Protein expression of Akt, Akt1, Akt2, phospho-Akt Thr308, phospho-Akt Ser473, PDK1, phospho-PDK1 Ser241, SGK, phospho-SGK Ser255/Thr256, CREB, phospho-CREB Ser133, FAS, p70S6 kinase, phospho-p70 S6 kinase Thr421/Ser424, mTOR, phospho-mTOR Ser2448, phospho-mTOR Ser2481, GSK3 $\alpha$, phospho-GSK3 $\alpha$ Ser21, GSK3 $\beta$, phospho-GSK3 $\beta$ Ser9, Bcl-2, p38 MAPK, phospho-p38 MAPK Thr180/Tyr182, p90RSK, phospho-p90RSK S380, Bad, Bax, CKI, CKII $\alpha$, CKII $\beta$, Chk1, Chk2, phospho-ATM S1981, phospho-ATR S428, and TRIB3 in LNCaP 104-R1 cells treated with 0, 10, 20, and $40 \mu \mathrm{M} \mathrm{CAPE}$ for $96 \mathrm{~h}$ were assayed by Western blotting. Protein abundance of $\alpha$-tubulin and $\beta$-actin was used as loading control. (B) Proteins expression level was organized in the y-axis of the heatmap based on time of maximal fold change amplitude. Green color indicated decrease of protein expression while red color indicated increase of protein expression under treatment of CAPE.

\section{Clinical implication of p53 induction}

Analysis of Oncomine database suggested that PCa tumors expressed less Tp53 as compared to normal prostate epithelial tissues (Figure 13A, 13B). Since CAPE treatment significantly increased abundance of p53 protein, CAPE treatment is thus a potential effective therapy for PCa.

\section{DISCUSSION}

Our observations implied that CAPE treatment at dosage 10-20 $\mu \mathrm{M}$ can effectively suppressed the proliferation, survival, soft agar colony formation, and tumor growth of CRPC cells via induction of G1 or G2/M cell cycle arrest. The achievable physiological concentration of CAPE in human serum is $17 \mu \mathrm{M}$ [27], therefore, administration of CAPE is a possible treatment for CRPC. CAPE is distributed extensively into animal tissues and is eliminated rapidly with a short half life [28]. Toxicology study revealed that i.p. injection of $10 \mathrm{mg} /$ $\mathrm{kg}$ of CAPE did not show any toxicity on liver or kidney in mice study while i.p. injection of higher dose (20 and $30 \mathrm{mg} / \mathrm{kg}$ ) CAPE caused mild dose-dependent toxicity on liver and kidney [29]. CAPE treatment has also been shown to sensitize cancer cells to chemotherapeutic drugs and radiation treatment [30]. Therefore, treatment with CAPE not only may suppress CRPC tumor growth in patients but may also protect $\mathrm{PCa}$ patients from chemotherapy or radiation therapy.

The $\mathrm{p} 53$ protein is encoded by the Tp53 gene. The p53 protein is a main regulator of the cell cycle arrest and cellular senescence in response to short telomeres, DNA damage, oncogenes, supraphysiological mitogenic signals, 


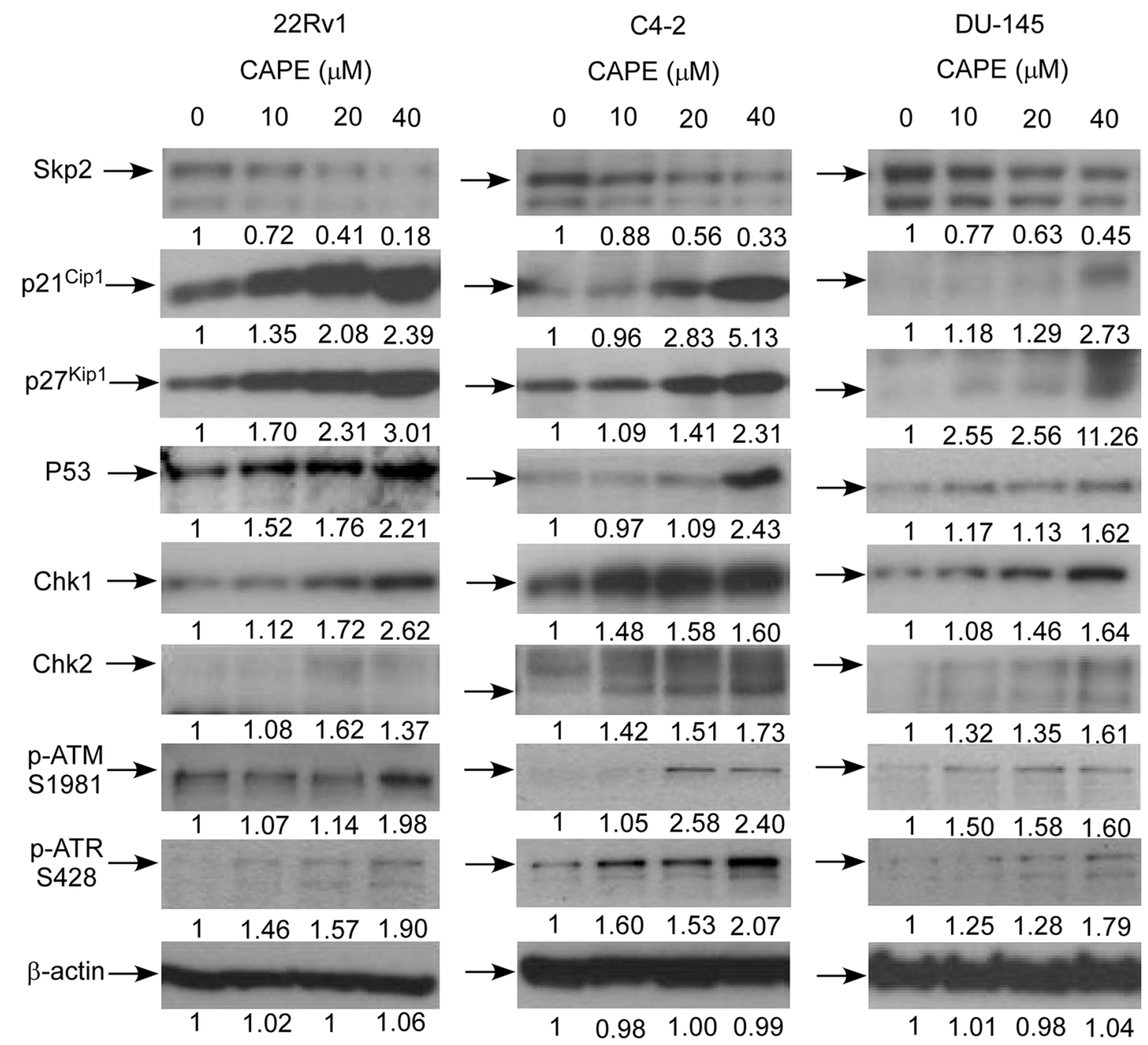

Figure 8: CAPE treatment affected abundance of proteins involved in cell cycle regulation and DNA damage checkpoint in CRPC cells. Protein expression of Skp2, p21 ${ }^{\text {Cipl } 1}$, p27 ${ }^{\mathrm{Kip} 1}$, p53, Chk1, Chk2, phospho-ATM S1981, phospho-ATR S428 in 22Rv1, LNCaP C4-2, and DU-145 cells treated with $0,10,20$, and $40 \mu \mathrm{M}$ CAPE for $96 \mathrm{~h}$ were assayed by Western blotting. Protein abundance of $\beta$-actin was used as loading control.

and tumor suppressor gene overexpression [31]. The p53 protein is negatively regulated by the $\mathrm{E} 3$ ubiquitin-protein ligase HDM2, which facilitates its degradation [32]. HDM2 is negatively regulated by the alternate-readingframe protein (ARF) [32]. The p53 protein establishes the cell cycle arrest in part by inducing the expression of $\mathrm{p} 21^{\mathrm{Cip} 1}$ [32]. The ATR kinase is a key transducer of genomic damage induced by oncogenes [33]. Activation of ATR is sufficient to promote cell cycle arrest and, if persistent, triggers p53-dependent but p16/ARFindependent senescence [34]. CAPE treatment can alter redox state and induce DNA damage in cancer cells [35]. ATR is a serine/threonine-specific protein kinase which is the sensor for DNA damage [36-38]. ATR activates the DNA damage checkpoint, which leads to cell cycle arrest [33, 37, 38]. Persistent single-stranded DNA activates ATR [33, 37, 38]. Activated ATR then phosphorylates
Chk1, initiating a signal transduction cascade that culminates in cell cycle arrest [33]. ATM (Ataxia telangiectasia mutated) is a serine/threonine protein kinase which is recruited and activated by DNA doublestrand breaks. It phosphorylates p53, Chk2, H2AX, and other tumor suppressors, which initiates the activation of the DNA damage checkpoint and leads to cell cycle arrest, DNA repair or apoptosis, [39]. Upon DNA damage, ATM autophosphorylates on residue Ser1981, stimulating the dissociation of ATM dimmers and is therefore followed by the release of active ATM monomers [40]. The ATMmediated DNA damage response consists of both the rapid and the delayed response. ATM phosphorylates and activates the effector kinase Chk2 [41, 42]. Activated Chk2 then phosphorylates phosphatase CDC25A, which is degraded and is unable to dephosphorylate Cdk2-Cyclin, resulting in cell-cycle arrest [41, 42]. If the DSB can not 


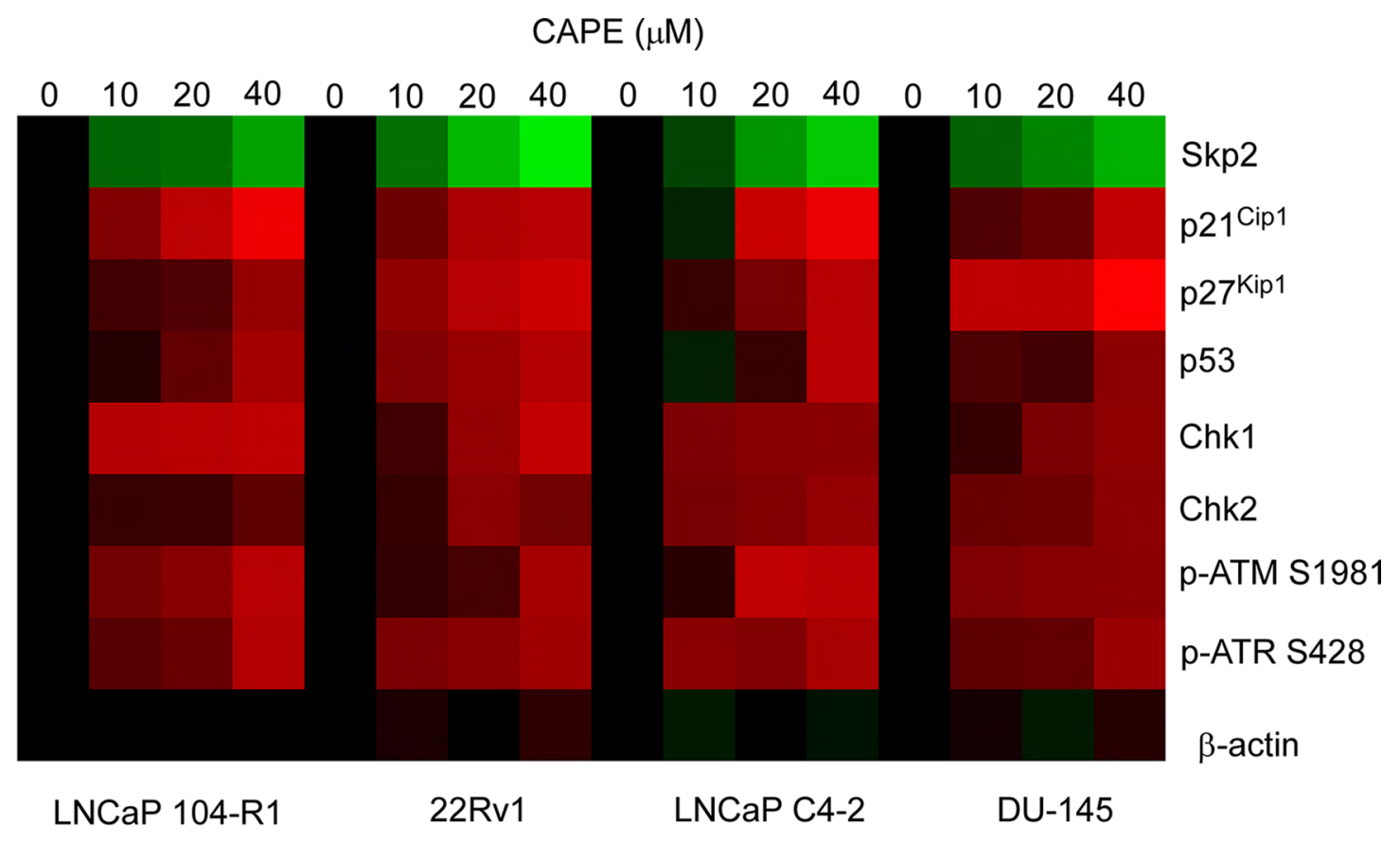

Min -3.49

$\operatorname{Max} 3.49$

Figure 9: Expression pattern of cell cycle regulation and DNA damage checkpoint proteins in CRPC cells being treated with CAPE. Proteins expression of Skp2, p2 $1^{\text {Cipl }}$, p27 ${ }^{\text {Kip1 }}$, p53, Chk1, Chk2, phospho-ATM S1981, phospho-ATR S428 in LNCaP 104-R1, 22Rv1, LNCaP C4-2, and DU-145 cells treated with 0, 10, 20, and $40 \mu \mathrm{M}$ CAPE for $96 \mathrm{~h}$ assayed in Figure 6 and Figure 8 was organized in the y-axis of the heatmap based on time of maximal fold change amplitude. Green color indicated decrease of protein expression while red color indicated increase of protein expression under treatment of CAPE.

be repaired during this rapid response, ATM with then phosphorylate MDM2 and p53 at Ser15 [41,42]. p53 is also phosphorylated by the effector kinase Chk2 [41, 42]. These phosphorylation finally lead to stabilization and activation of p53 and subsequent transcription of several p53 target genes including p $21^{\text {Cip } 1}$ and therefore induce long-term cell-cycle arrest or apoptosis [41, 42]. Chk1 is a serine/threonine protein kinase and is a key regulator of genome stability, cell cycle, and cell survival [43]. Chk1 coordinates the DNA damage response [44]. Chk1 is regulated by ATR through phosphorylation. Activation of Chk1 results in the initiation of cell cycle checkpoints, cell cycle arrest, DNA repair, or even apoptosis [44-46]. Activation of Chk1 holds the cell in the G2 phase until ready to enter the mitotic phase. Chk1 is also essential for the cell to enter S or M phase [45, 46]. Chk2, is a protein kinase that is activated in response to DNA damage and is involved in cell cycle arrest [47]. Activated Chk2 inhibits Cdc5c phosphatase, prevents entry into mitosis phase, stabilizes the tumor suppressor protein $\mathrm{p} 53$, and leads to G1 cell cycle arrest [48]. CAPE treatment significantly reduced protein abundance of Skp2 and induced protein level and phosphorylation of p53, ATM, and ATR, as well as the abundance of $\mathrm{p} 21^{\text {Cipl }}, \mathrm{p} 27^{\mathrm{Kip} 1}$, Chk1, and Chk2 protein in CRPC cells (Figures 6, 8, 9). These changes may contribute to the induction of cell cycle arrest in CRPC cells.
As mentioned by Dr. Blagosklonny, cell cycle arrest is not yet senescence $[23,24]$. When the cell cycle is arrested, an inappropriate growth-stimulation, such as activation of mTOR, converts the cell cycle arrest into cellular senescence [23, 24]. Properties of cellular senescence include a large flat morphology, SA- $\beta$-gal staining, feedback signal resistance, and loss of regenerative potential [24]. According to the facts that CRPC cells treated with CAPE did not show enlargement, and CAPE treatment suppressed mTOR signaling related proteins (Figure 7), only a portion of cells showed positive SA- $\beta$-gal staining, and some cells still proliferate under CAPE treatment, we believe that CAPE treatment induced quiescence cell cycle arrest but not cellular senescence. Hypoxia can increase content and functions of lysosomal, which may display as moderate SA- $\beta$-Gal-staining in cells [25]. In some cells, hypoxia can slow down cell proliferation and cause cell cycle arrest [25]. Under hypoxic conditions, cells are relatively small, whereas senescent cells are large and flat [25]. Hypoxia-arrested cells can resume proliferation when being placed under normoxia [25]. We therefore believe that CAPE treatment triggered hypoxia-induced cell cycle arrest/quiescence in LNCaP 104-R1 cells.

Skp2 is an F-box protein belongs to the SCF (Skp1-Cullin 1-F-box protein) E3 ubiquitin ligase complex which regulates the $\mathrm{S}$ phase entry of cells by 

pSR $\alpha$ plasmid control

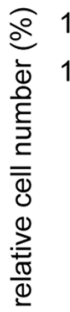
$\square$ pMV7 plasmid control $\square$ Skp2 overexpression

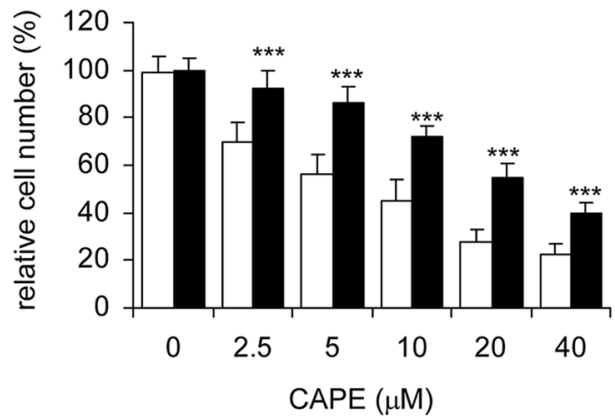

C

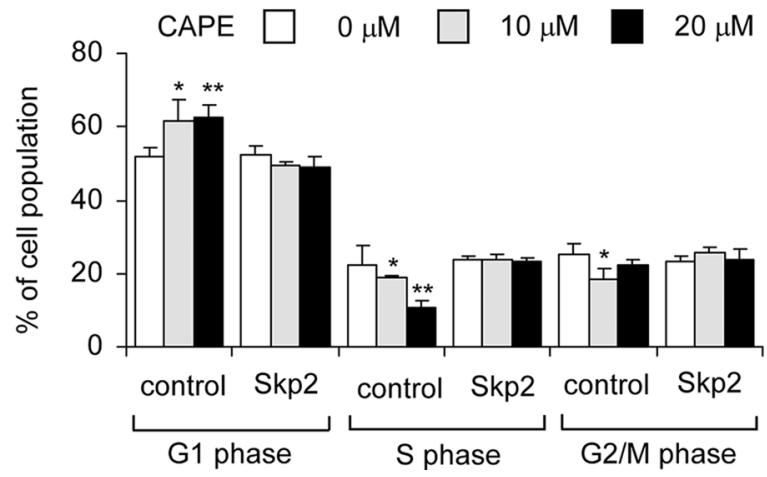

D

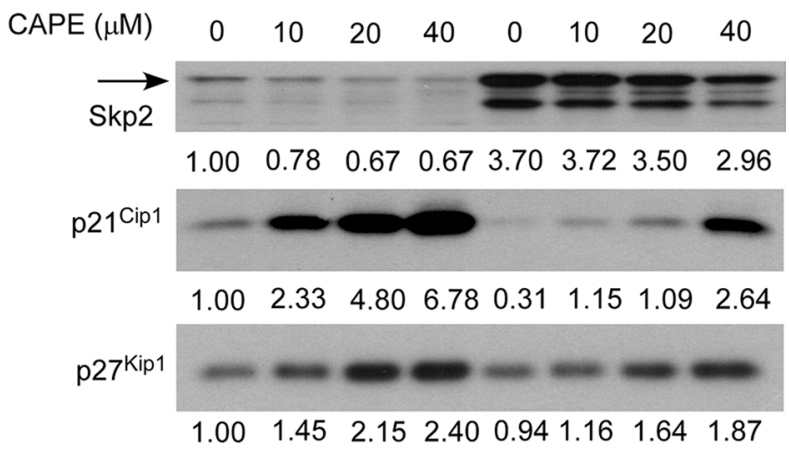

cyclin D1

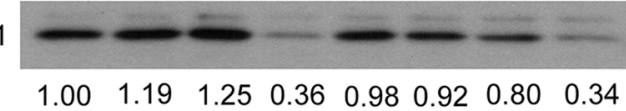

Cdk2

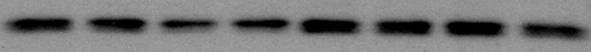

$\begin{array}{llllllll}1.00 & 0.91 & 0.68 & 0.76 & 1.08 & 0.99 & 1.06 & 0.93\end{array}$

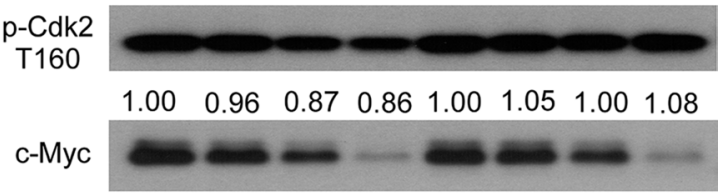

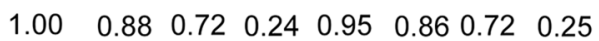

$\alpha$-tubulin

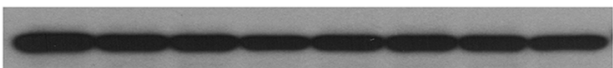

$\begin{array}{llllllll}1.00 & 0.98 & 0.97 & 0.97 & 0.98 & 0.97 & 0.96 & 0.99\end{array}$

$\beta$-actin

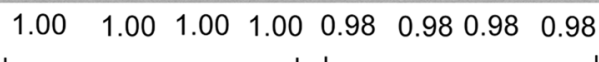

LNCaP 104-R1 LNCaP 104-R1-Skp2

Figure 10: Over-expression of Skp2 blocked the suppressive effect of CAPE on proliferation of LNCaP 104-R1 cells. LNCaP 104-R1 cells overexpressing Akt1 (A) or Skp2 (B) and their plasmid control cells were treated with increasing concentrations of CAPE for $96 \mathrm{hr}$ and analyzed by 96-well proliferation assay for cell proliferation. (C) LNCaP 104-R1 cells overexpressing with Skp2 or control plasmid were treated with 0,10 , or $20 \mu \mathrm{M}$ CAPE for $96 \mathrm{~h}$, harvested, and stained with propidium iodide dye for flow cytometric analysis of cell cycle distribution. (D) Protein expression of Skp2, p21 ${ }^{\mathrm{Cip} 1}, \mathrm{p} 27^{\mathrm{Kip} 1}$, cyclin D1, Cdk2, phospho-Cdk2 T160, and c-Myc were assayed by Western blotting in LNCaP 104-S cell lines overexpressing Skp2 or vector control prior to CAPE treatment. Protein abundance of $\alpha$-tubulin and $\beta$-actin was used as loading control.

inducing the degradation of the cyclin-dependent kinase (Cdk) inhibitors p21 $1^{\text {Cip1 }}$, p27 Kip1, p57, p130, Tob1, and FoxO1 [49-51]. Skp2 targets Cdk inhibitor p27 ${ }^{\text {Kip1 }}$ by phosphorylating $\mathrm{p} 27^{\mathrm{Kip} 1}$ at $\mathrm{T} 187$ for ubiquitination and degradation [52-54]. Both luminal and basal epithelial cells in normal prostate exhibit very low Skp2 levels, however, Skp2 levels increase dramatically in both prostatic intraepithelial neoplasm (PIN) and PCa [49, 55]. Up-regulation of Skp2 correlates to lower $\mathrm{p} 27^{\mathrm{Kip}}$ expression, higher Gleason score, more advanced pathological stage, and recurrence in $\mathrm{PCa}$ patients [55-57]. Up-regulation of Skp2 in $\mathrm{PCa}$ patient is an independent factor for prediction of higher risk of $\mathrm{PCa}$ recurrence after surgery $[55,56]$. Skp2 overexpression in PCa cells stimulates PCa cell proliferation and increases the tumorigenesis in xenograft tumor model [58]. Tissuespecific over-expression of Skp2 in prostate promotes proliferation, hyperplasia, dysplasia, and low-grade carcinoma in the prostate gland [59]. Deficiency of Skp2 in vivo triggers cellular senescence via up-regulation of $\mathrm{p} 21^{\mathrm{Cip} 1}, \mathrm{p} 27^{\mathrm{Kip} 1}$, and ATF4, therefore suppresses the development of PCa [60]. Skp2 was reported to cross-talk with PI3K/Akt [61], AR [62], PTEN [55], and BRCA2 [63] signaling pathways in PCa cells. As a result, Skp2 

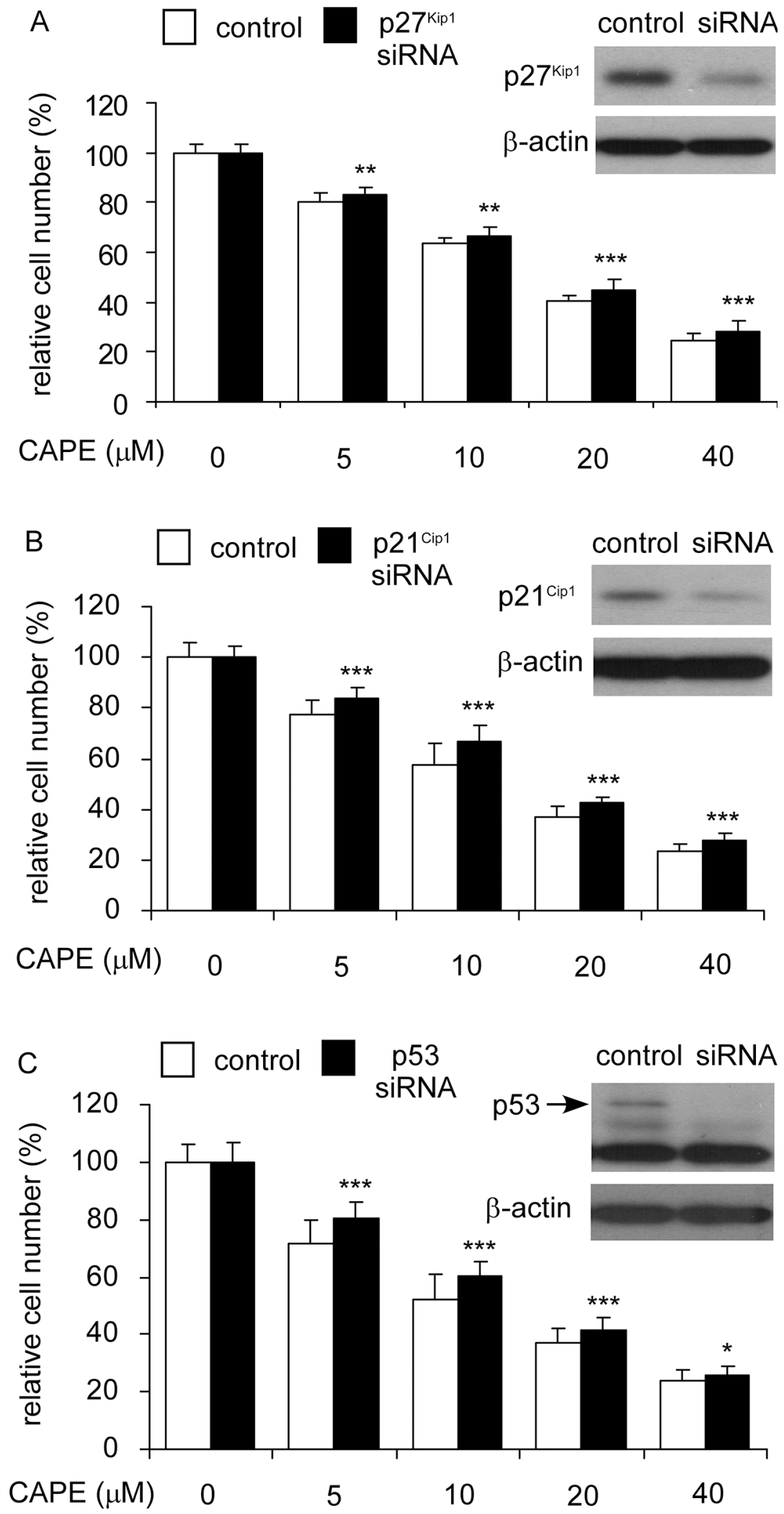

Figure 11: Over-expression of p27Kip1, p21Cip1, and p53 blocked the suppressive effect of CAPE on proliferation of LNCaP 104-R1 cells. LNCaP 104-R1 cells overexpressing p2 $7^{\mathrm{Kipl} 1}(\mathbf{A})$, p2 $1^{\mathrm{Cipl}}(\mathbf{B})$, or p53 (C) and their plasmid control cells were treated with increasing concentrations of CAPE for $96 \mathrm{hr}$ and analyzed by 96 -well proliferation assay for cell proliferation. Overexpression of $\mathrm{p} 27^{\mathrm{Kipl}}, \mathrm{p} 21^{\mathrm{Cip} 1}$, and 553 proteins was confirmed by Western blotting. Protein abundance of $\beta$-actin was used as loading control. 

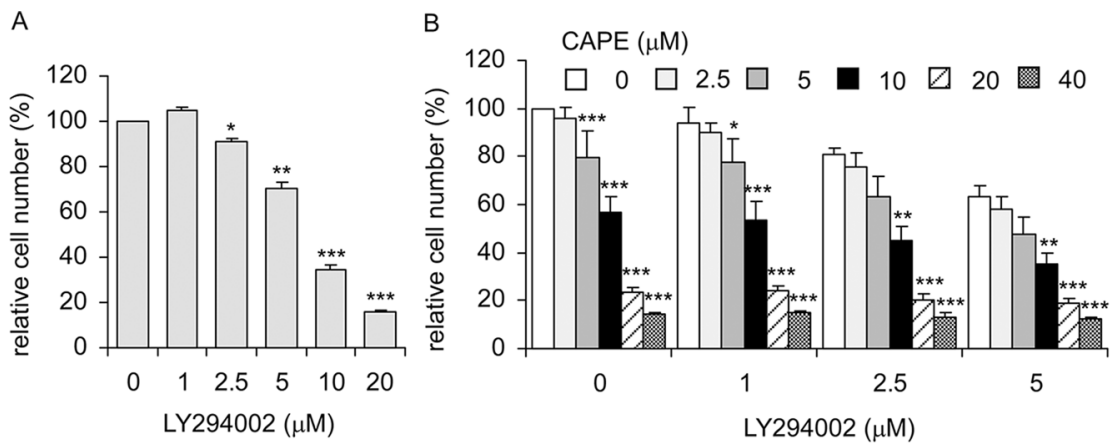

C
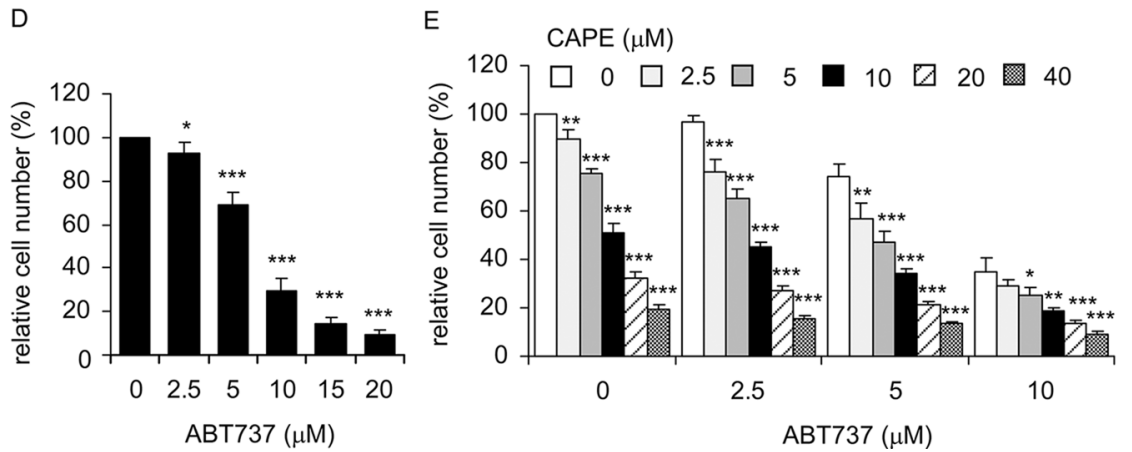

\begin{tabular}{|c|c|c|c|}
\hline & $1 \mu \mathrm{M}$ & $2.5 \mu \mathrm{M}$ & $5 \mu \mathrm{M}$ \\
\hline $2.5 \mu \mathrm{M}$ & 1.1 & 1.2 & 1.2 \\
\hline $5 \mu \mathrm{M}$ & 1.1 & 1.2 & 1.2 \\
\hline $10 \mu \mathrm{M}$ & 1.1 & 1.1 & 1.1 \\
\hline $20 \mu \mathrm{M}$ & 1.0 & 1.1 & 0.9 \\
\hline $40 \mu \mathrm{M}$ & 1.0 & 1.0 & 0.8 \\
\hline
\end{tabular}

$\mathrm{F}$

\begin{tabular}{|c|c|c|c|}
\hline & \multicolumn{3}{|c|}{ ABT737 } \\
\hline & $2.5 \mu \mathrm{M}$ & $5 \mu \mathrm{M}$ & $10 \mu \mathrm{M}$ \\
\hline $2.5 \mu \mathrm{M}$ & 1.1 & 1.1 & 0.9 \\
\hline $5 \mu \mathrm{M}$ & 1.1 & 1.1 & 0.9 \\
\hline $10 \mu \mathrm{M}$ & 1.1 & 1.0 & 0.8 \\
\hline $20 \mu \mathrm{M}$ & 1.1 & 1.0 & 0.7 \\
\hline $40 \mu \mathrm{M}$ & 1.2 & 1.0 & 0.6 \\
\hline
\end{tabular}

Figure 12: Combined treatment of CAPE with PI3K inhibitor LY294002 or BCl-2 inhibitor ABT737 showed additive and mild synergistic inhibition on proliferation of LNCaP 104-R1 cells. Proliferation of LNCaP 104-R1 cells treated with increasing dosage $(0,5,10,20 \mu \mathrm{M})$ of LY294002 (A), combination of CAPE and LY294002 (B), ABT737 (D), and combination of CAPE with ABT737 (E) was determined by 96-well proliferation assay. The ration of expected cell number/observed cell number of LNCaP 104-R1 cells treated with combination of CAPE and LY294002 (C) or combination of CAPE and ABT737 (F) was shown. The effect of the combined treatment was determined by the ratio of expected cell number/observed cell number. For example, treatment of 104-R1 cells with $5 \mu \mathrm{M}$ of ABT737 decreased the cell number to $69.2 \%$ and treatment with 104-R1 cells with $5 \mu \mathrm{M}$ CAPE alone decreased the cell number to $75.6 \%$. The expected cell number of treatment combining $5 \mu \mathrm{M}$ of ABT737 with $5 \mu \mathrm{M}$ CAPE was $0.692 \times 0.756=52.3 \%$. The actual observed cell number is $47.0 \%$. The ratio of expected cell number/observed cell number is $0.523 / 0.470=1.1$. Ratio larger than one represents synergy of growth inhibition as the combined treatment of two drugs suppressed more cells than either drug alone. If the observed cell number is less than the cell number being treated with any one of the drug alone, this indicates additive suppressive effect of the combination treatment of the two drugs. For example, treatment of 104-R1 cells with $2.5 \mu \mathrm{M}$ of LY294002 decreased the cell number to $91.2 \%$, while treatment with 104-R1 cells with $40 \mu \mathrm{M}$ CAPE decreased the cell number to $14.5 \%$. The combination of $2.5 \mu \mathrm{M}$ of LY294002 with $40 \mu \mathrm{M}$ CAPE decreased the cell number to $13.1 \%$, then we called the combination of $2.5 \mu \mathrm{M}$ of LY294002 with $40 \mu \mathrm{M}$ CAPE exhibited additive suppressive effects on LNCaP 104-R1 cells.

plays essential role in the development and progression of human PCa [49]. Development of compounds targeting Skp2 may be a useful strategy for the treatment of patients with CRPC. We discovered that overexpression of Skp2 reduced the accumulation of $\mathrm{p} 21^{\mathrm{Cip} 1}$ and $\mathrm{p} 27^{\mathrm{Kip} 1}$ as well as lessen the decrease of Cdk2 and phospho-Cdk2 T160 caused by CAPE treatment (Figure 10). CAPE treatment reduced protein expression of Skp2 but induced protein abundance of $\mathrm{p} 21^{\mathrm{Cip} 1}, \mathrm{p} 27^{\mathrm{Kip} 1}, \mathrm{p} 53$, and ATF4 (Figures 4-6, $8,9)$. Changes of these proteins may contribute to the induction of cell cycle arrest in CRPC cells.

Cyclin A is a member of the cyclin family. Transcription of cyclin A is tightly regulated and synchronized with cell cycle progression by the transcription factor E2F in a negative feedback loop [64]. Both cyclin A and E2F were suppressed by CAPE treatment (Figure 6). Cdk2 is a member of the cyclindependent kinase family of serine/threonine protein kinases [65]. Complex of Cdk2 and cyclin A is required to progress through the $\mathrm{S}$ phase, while binding between Cdk2-cyclin $\mathrm{E}$ is required for the transition of cells from G1 to S phase [65]. Activation of Cdk2 complexes requires phosphorylation of Thr 160 on Cdk 2 by Cdk 7 and cyclin $\mathrm{H}[66]$ as well as dephosphorylation of Thr14 and Tyr15 on Cdk2 by cdc25 phosphatase. Although CAPE treatment did not alter phosphorylation of Thr14 and Tyr 15 on Cdk2, it repressed phosphorylation of Thr160 on Cdk2 (Figure 6), which will suppress the activity of Cdk2. Skp2 is phosphorylated by Cdk2 at Ser64 [54] and by Akt at Ser72 [67]. Phosphorylation of Ser64 and Ser72 on Skp2 regulates the stabilization of Skp2 by preventing its association with APC/CCdh1 [51, 52, 54, 67]. Protein abundance and phosphorylation of Cdk2 and Akt were both declined by CAPE treatment (Figures 6, 7). CAPE treatment may therefore reduce the stability of Skp2, resulting in reduction of Skp2 protein abundance. Cdk4 is a serine/threonine protein kinase which is important for cell cycle G1 phase progression [68]. The activity of 

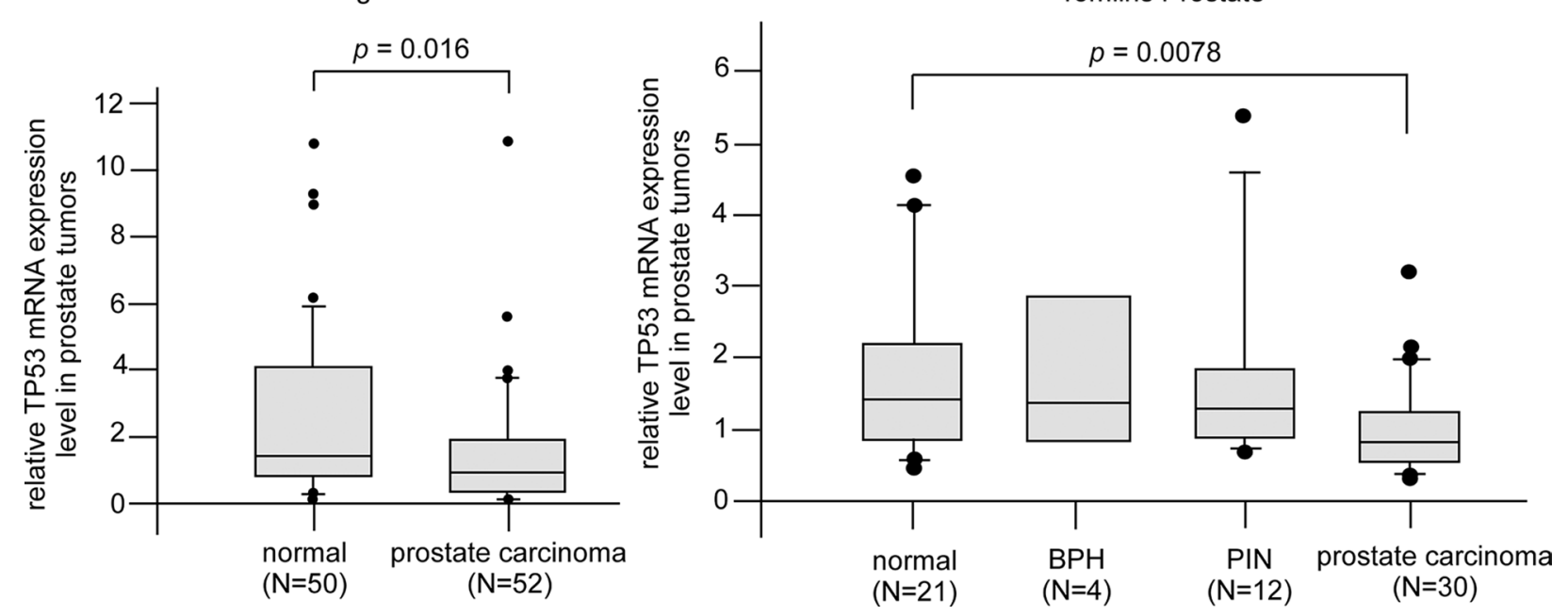

Figure 13: Gene expression of Tp53 in PCa patient oncomine database. (A) Expression of Tp53 gene was detected by reporter probe 1974_s_at in 50 normal prostate gland samples and 52 prostate carcinoma samples from Singh prostate datasets using gene microarray [108]. (B) Expression of Tp53 gene was detected by reporter probe IMAGE:24415 in 21 normal prostate gland epithelial samples, 4 BPH (benign prostatic hyperplasia), 12 PIN (prostatic intraepithelial neoplasia), and 30 prostate carcinoma samples from Tomlins prostate datasets using gene microarray [109]. Data were downloaded from Oncomine (http://www.oncomine.com) without further processing.

$\mathrm{Cdk} 4$ is controlled by CDK inhibitor $\mathrm{p} 16^{\mathrm{INK} 4 \mathrm{a}}$. $\mathrm{Cdk} 4$ is responsible for the phosphorylation of retinoblastoma $(\mathrm{Rb})$ [68]. CAPE treatment suppressed abundance of Cdk4, $\mathrm{Rb}$, and phosphor-Rb Ser807/811 (Figure 6). Complex between Cyclin D and Cdk4 or Cdk6 are key player for G1/S transition in cell cycle progression [69]. Expression of cyclin D1 was significantly reduced by CAPE treatment. As a result, CAPE treatment may interfere the cell cycle progression and induced $\mathrm{G} 1$ or $\mathrm{G} 2 / \mathrm{M}$ cell cycle arrest by suppressing the protein abundance and activity of Skp2, Cdk2, Cdk4, Cdk7, cyclin A, cyclin D1, cyclin $\mathrm{H}, \mathrm{E} 2 \mathrm{~F} 1$, and c-Myc as well as by inducing $\mathrm{p} 21^{\mathrm{Cip} 1}$ and p2 $7^{\text {Kip1 }}$.

Phosphatase and tensin homolog (PTEN) protein is a negative regulator for PI3K-Akt signaling pathway [70]. PTEN is frequently deleted or mutated in prostatic intraepithelial neoplasia $(\mathrm{PIN})$ and $\mathrm{PCa}$, giving rise to elevation of phosphoinositide 3-kinase (PI3K)/Akt signaling [71, 72]. Up-regulation of PI3K/Akt activity is associated with poor clinical outcome of $\mathrm{PCa}$ [72-78]. Akt is a serine/threonine protein kinase with three isoforms, the Akt1, Akt2, and Akt3 [79, 80]. Two phosphorylation sites on Akt, threonine 308 and serine 473, regulate activity of Akt. Phosphorylation of Thr308 on Akt is activated by PDK1 [81], while the phosphorylation of serine 473 on Akt is activated by mTOR kinase, its associated protein rector, and SIN1/MIP1 [82, 83]. Akt phosphorylation level correlates with higher Gleason score [84, 85]. CAPE treatment caused mild but dose-dependent repression of Akt1, Akt2, as well as phosphorylation of Akt and PDK1 (Figure 7). This explained why co-treatment of (PI3K)-Akt inhibitor LY294002 showed synergistic suppressive effect (Figure 12). The mammalian target of rapamycin (mTOR) is also a serine/threonine protein kinase $[86,87]$. The mTOR protein is phosphorylated at Ser2448 via the PI3 kinase/Akt signaling pathway and autophosphorylated at Ser2481 [88, 89]. CAPE treatment significantly suppressed the phospho-mTOR Ser2481 and phospho-p70S6kinase, a downstream signaling protein of mTOR pathway $[90,91]$, while caused a relatively mild suppression on mTOR and phosphor-mTOR Ser2448 (Figure 7). As mTOR and p70 S6 kinase function as ATP and amino acid homeostasis sensor, regulator protein synthesis, balance nutrient uptake, and control cell proliferation $[92,93]$, their inhibition caused by CAPE treatment may interfere nutrient balance, protein synthesis, and diminish cell proliferation in CRPC cells. TRIB3 is a putative protein kinase and is induced by NF- $\mathrm{BB}[94,95]$. TRIB3 is a negative regulator of NF- $\mathrm{BB}$ and Akt1 [94, 95]. We observed that CAPE treatment significantly increased protein level of TRIB3, which may contribute to inhibitory roles of CAPE on NF- $\mathrm{BB}$ [17] and Akt1 (Figure 7).

$\mathrm{Rb}$ restricts cell cycle progression from the G1 phase to $\mathrm{S}$ phase [96-98]. Rb binds and inhibits transcription factors of the E2F family, which will result in G1 cell cycle arrest [96-98]. Phosphorylation of Rb is performed by cyclin $\mathrm{D} / \mathrm{Cdk} 4 / \mathrm{Cdk} 6$ and following by cyclin E/Cdk2. Phosphorylation of Rb blocks its binding to E2F and therefore allow the cells to progress from G1 phase to the $\mathrm{S}$ phase [96-98]. Rb remains phosphorylated throughout $\mathrm{S}, \mathrm{G} 2$, and $\mathrm{M}$ phases. It is very interesting that we observed CAPE treated not only reduced the protein expression of E2F1 and phospho-Rb Ser807/811, but it also decreased the abundance of Rb. Previously, researchers observed that chemotherapeutic drug honokiol treatment induced G1 cell cycle arrest, growth inhibition, 


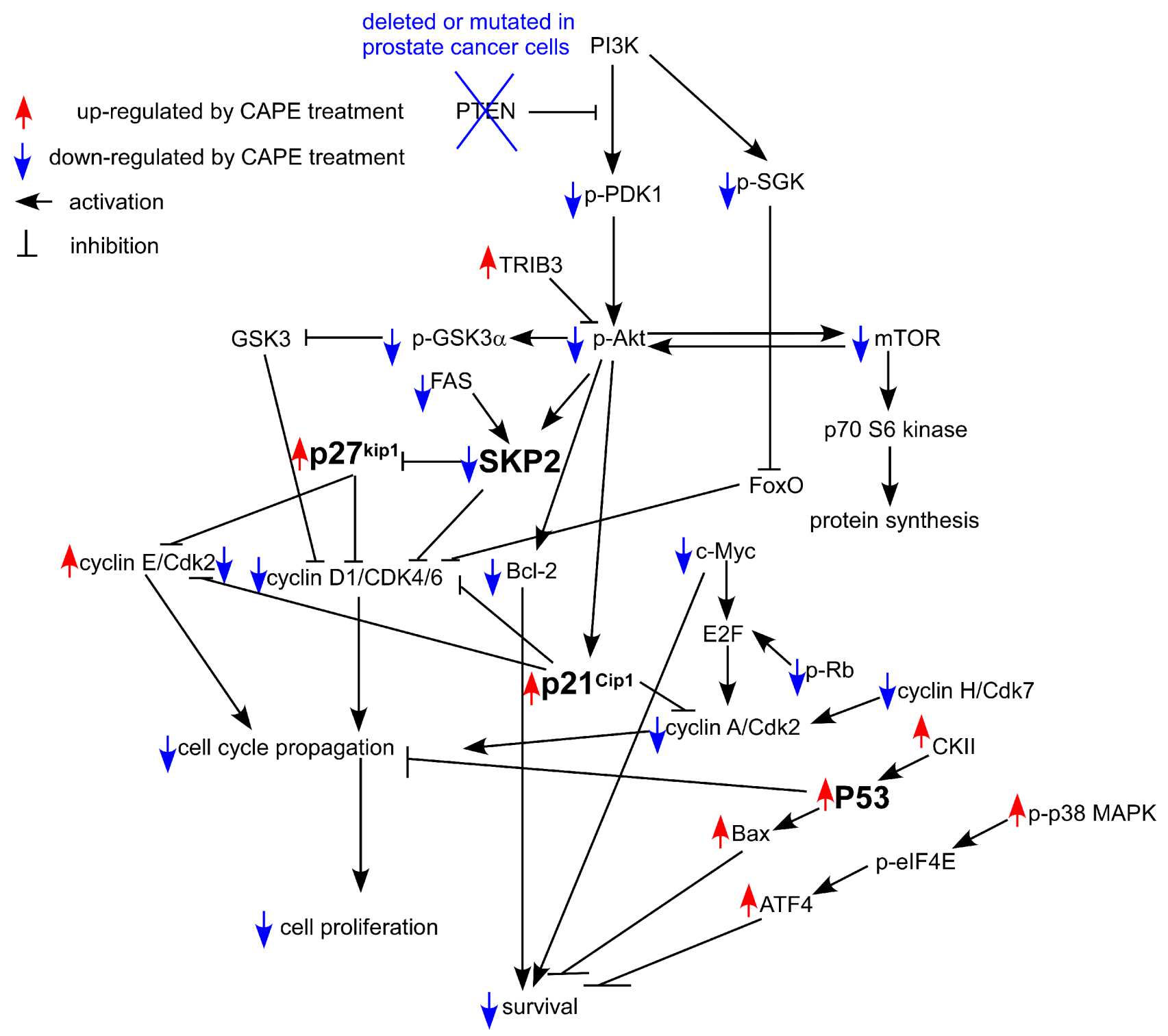

Figure 14: Putative model of anti-cancer effect of CAPE in human CRPC cells. Protein abundance or activity being stimulated by CAPE treatment are labeled with red upward arrows, while those being suppressed by CAPE treatment are labeled with blue downward arrows. Arrows indicated activation of downstream signaling proteins, while bars means inhibition of downstream signaling proteins.

and induction of $\mathrm{p} 21^{\mathrm{Cip} 1}$ and $\mathrm{p} 53$ in PC-3 and LNCaP cells [99]. Honokiol treatment significantly decreased in the levels of total and phosphorylated $\mathrm{Rb}$, which correlated with the reduction of E2F1 transcriptional activity [99]. The authors concluded that honokiol treatment decreased protein levels of Cdk4, cyclin D1, and Rb via induction of proteasomal degradation [99]. We believe that CAPE also induced proteasomal degradation of Rb, cyclin $\mathrm{D} 1$, and Cdk4 in CRPC cells similar to honokiol as the response of CRPC cells to CAPE treatment is very similar to that of LNCaP cells being treated with honokiol.

Our observation suggested that inhibition of Skp2 and induction p53, p2 $1^{\text {Cip1 }}$ and $\mathrm{p} 27^{\mathrm{Kip} 1}$ was essential for growth inhibition promoted by CAPE treatment in CRPC cells. Not only did CAPE treatment suppressed Skp2 protein expression while increased protein abundance of p53, p2 $1^{\text {Cipl }}$ and p27 $7^{\text {Kipl } 1}$ (Figures 8, 9), but overexpression of Skp2 or siRNA knockdown of p53, p2 $1^{\text {Cip1 }}$ and p $27^{\text {Kip } 1}$ also partially blocked the suppressive effect of CAPE on CRPC cells (Figures 10,11). We summarize all the signaling pathways being affected by CAPE treatment in CRPC cells in Figure 14.

We noticed that some Micro-Western Array revealed that CAPE treatment induced protein expression of Cdk2, cyclin D1, cyclin A, and SGK (Figure 5), while conventional Western blotting assay indicated that the abundance of these proteins was reduced by CAPE treatment (Figures 6, 7). According to our experience, 
there are approximately 5-20\% inconsistency between MWA and conventional Western blot. The inconsistency is usually due to air bubbles affecting the image quality during protein transfer, weak signaling of certain MWA results, or cross-reactivity of certain antibodies. In Figure 10, the signal of Cdk2 was very weak, while the inconsistent results of SGK, cyclin A, and cyclin D1 may be affected by cross-reactivity of antibodies. We suggested that MWA can be used as a high-throughput screening tool similar to gene microarray while conventional Western blotting should be used to confirm the results as using RTPCR for gene array confirmation.

The $\mathrm{IC}_{50}$ of CAPE treatment for AR-positive androgen-dependent LNCaP 104-S cells was $0.68 \mu \mathrm{M}$ [19]. Compared to the parental LNCaP 104-S cells, 104$\mathrm{R} 1$ cells is 28 fold more resistant to CAPE treatment. Under the culture condition, the protein abundance of Skp2, p21 ${ }^{\text {Cip } 1}$, p2 $7^{\text {Kip1 }}$, p53, total Akt, Akt1, Akt2, phosphoAkt S473, and phospho-Akt T308 are similar in 104-S and 104-R1 cells [21]. However, the protein level of Bcl-2 in 104-R1 cells is 65 fold higher than that in 104-S cells [21], and CAPE treatment caused very little inhibition on Bcl-2 level (Figure 12). Bcl-2 is an anti-apoptotic oncoprotein. Normal human prostate epithelial cells do not express the bcl-2 protein [100]. Up-regulation of Bcl-2 is necessary for the progression of LNCaP prostate cancer cells from an androgen-dependent to an androgen-independent growth stage $[100,101]$. It is therefore very possible that high expression level of Bcl-2 proteins allows 104-R1 cells to be more resistant to CAPE treatment as compared to 104-S cells. In support of this hypothesis, co-treatment of Bcl-2 inhibitor ABT737 with CAPE showed synergistic suppressive effect (Figure 12), providing the rationale of using CAPE in combination with Bcl-2 for treatment of patients with CRPC.

We found that Tp53 gene level is lower in prostate tumors as compared to normal prostate epithelial tissue from Oncomine database analysis (Figure 13). Since CAPE treatment significantly increased abundance of p53 protein in CRPC cell lines, CAPE treatment may thus benefit patients with advanced prostate cancers.

\section{MATERIAL AND METHODS}

\section{Chemicals}

Caffeic acid phenethyl ester (CAPE) and LY294002 (PI3K inhibitor) were purchased from Sigma (St. Louis, MO, U.S.A.). CAPE was dissolved in ethanol for all cell experiments. RevertAid H Minus First Strand cDNA Synthesis Kit and SYBR Green/ROX qPCR Master Mix were purchased from Fermentas (Waltham, Massachusetts, U.S.A.). ABT737 (Bcl-2 inhibitor) was purchased from Santa Cruz (Santa Cruz, CA, U.S.A.). Matrigel was purchased from BD Bioscience (Franklin Lakes, NJ, U.S.A.).

\section{Cell culture}

LNCaP 104-R1 cells were derived from parental androgen-dependent LNCaP 104-S cells, which were generated from LNCaP FGC clone (ATCC CRL-1740) as previously described $[14,102]$. LNCaP 104-R1 cells were maintain in DMEM with 10\% charcoal-stripped FBS (CS-FBS). PC-3, LNCaP C4-2, 22Rv1, and DU-145 cells were purchased from Bioresource Collection and Research Center (Hsinchu city, Taiwan). PC-3, LNCaP C4-2, 22Rv1, and DU-145 cells were maintained in DMEM (Gibco/Invitrogen, Carlsbad, CA, U.S.A.) supplemented with $10 \%$ fetal bovine serum (FBS; Atlas Biologicals, Fort Collins, CO, U.S.A.), penicillin (100 U/ml), and streptomycin $(100 \mu \mathrm{g} / \mathrm{ml})$ as previously described [21].

\section{Hoechst and DAPI staining miscroscopy}

CRPC cells were seeded in 8 well chamber slide at a concentration of $1 \times 10^{4}$ per well and was allowed to attach overnight. Cells were then treated with different concentration of CAPE $0,2.5,5,10,20$ and $40 \mu \mathrm{M}$ for 96 h. After 96 h, cells were rinsed twice with PBS and fixed with $4 \%$ formaldehyde for 15 minutes. Cells were then rinsed with PBS three times, each time for $5 \mathrm{~min}$. After the rinsing, the fixed cells were Incubated in blocking buffer $(5 \% \mathrm{BSA}+0.1 \%$ triton $\mathrm{x}-100$ in PBS) overnight under at $4^{\circ} \mathrm{C}$. After the blocking, cells were rinsed with PBS for three times, each time for 5 min. Finally, cells were stained with diluted 1:4000 Hoechst (stock solution $10 \mathrm{mg} / \mathrm{mL}$ ) or DAPI ( $5 \mathrm{mg} / \mathrm{mL}$ ) for $15 \mathrm{~min}$ and should be kept away from light exposure. Cells were then mounted into the slide and microscope images were captured at magnification of $100 \mathrm{X}$.

\section{Cell proliferation assay}

LNCaP 104-R1 cells, PC-3, LNCaP C4-2, 22Rv1, and DU-145 cells were seeded at a density of $3 \times 10^{3}$ cells/well in 96-well plates with $100 \mu \mathrm{l}$ DMEM medium containing $10 \%$ CS-FBS with increasing concentration of CAPE. Relative cell number was analyzed by measuring the DNA content of cell lysates with the fluorescent dye Hoechst 33258 (Sigma, St. Louis, MO, USA) as described previously $[18,19,26,62]$. All readouts were normalized to the average of the control condition in each individual experiment. The experiment was repeated three times. Ten wells were used for each condition. The mean and standard deviation represented the average and standard deviation respectively of the results from all 30 wells in the three experiments.

\section{Cell viability assay}

LNCaP 104-R1 cells were seeded at a density of 3 $\times 10^{3}$ cells per well in a 96-well plate (BD Bioscience). After $24 \mathrm{~h}$, the cells were treated with increasing 
concentrations of CAPE for $96 \mathrm{~h}$. Cell viability was assessed by an MTT (3,4,5-dimethylthiazol-2-yl)-2-5diphenyltetrazolium bromide) assay [103]. The amount of formazan was determined by measuring the absorbance at $560 \mathrm{~nm}$ using an Tecan GENios ${ }^{\mathrm{TM}}$ plate reader (Tecan group Ltd, Männedorf, Switzerland) [103]. All results were normalized to the average of the control condition in each individual experiment. All experiments were repeated three times. Each time ten wells were utilized for each condition. The mean and standard deviation represented the results from all 30 wells in the three experiments.

\section{Soft agar colony formation assay}

We suspended 8,000 LNCaP 104-R1 cells in $0.3 \%$ low melting agarose (Lonza) with $10 \%$ CS-FBS in DMEM medium and then layered on top of $3 \mathrm{ml}$ of $0.5 \%$ low melting agarose plus $10 \% \mathrm{CS}-\mathrm{FBS}$ in DMEM medium in $6 \mathrm{~cm}$ dishes. Cells were allowed to grow at $37^{\circ} \mathrm{C}$ with $5 \% \mathrm{CO}_{2}$ for 14 days. The plates were stained with $0.005 \%$ crystal violet in $30 \%$ ethanol for $6 \mathrm{~h}$.

\section{Flow cytometric analysis}

After $96 \mathrm{~h}$ of culture in the presence of different concentrations of CAPE, cells were processed as previously described $[21,26,62]$. Cell cycle profiles of LNCaP 104-R1, DU-145, 22Rv1, and LNCaP C4-2 cells were determined by flow cytometric analysis using a BD Facscan flow cytometer (BD Biosciences, San Jose, CA). Data was analyzed using ModFit LT software (Verity Software House, Topsham, ME) as described [21, 26, 62].

\section{Western blotting analysis}

Cells were lysed in SDS lysis buffer (240 mM Trisacetate, 1\% SDS, 1\% glycerol, 5 mM EDTA pH 8.0) with DTT, protease inhibitors, and a cocktail of phosphatase inhibitors. Anti-rabbit and anti-mouse IgG secondary antibodies were from Invitrogen (Carlsbad, CA, U.S.A.) and LI-COR BioSciences (Lincoln, Nebraska). Akt, phospho-Akt Ser473, phospho-Akt Thr308, Rb, phosphoRb (S807/811), cyclin D1, cyclin E, Cdk2, phospho-Cdk2 Thr160, p38 MAPK, GSK3 $\alpha$, phospho-GSK3 $\alpha$ Ser21, GSK3 $\beta$, phospho-GSK3 $\beta$ Ser9, mTOR, phospho-mTOR Ser2481, phospho-CREB Ser133, phospho-ATM S1981, phospho-ATR S428, and Bax antibodies were purchased from Cell Signaling Technology (Danvers, MA, U.S.A.). Skp2, ATF-4, p2 $7^{\text {Kip } 1}$ and p21 $1^{\text {waf1/cip1 }}$ antibodies were from purchased Santa Cruz. P70S6kinase, phospho-P70S6K Thr241/Ser424, p53, phospho-p53 Ser6, phospho-p53 Ser33, phospho-p53 Ser46, phospho-p53 Ser392, fatty acid synthase (FAS), androgen receptor (AR), c-Myc, phospho-CDK2 Thr14, phospho-CDK2 Tyr15, CDK4, SGK, p90 RSK1, phospho-p90 RSK1 Ser380, PDK1, phospho-PDK1 Ser241, Casein Kinase I, Casein Kinase II $\alpha$, Casein Kinase II $\beta$, CREB, and $\alpha$-tubulin antibodies were purchased from Epitomics (Burlingame, CA, USA). Bcl-2 was purchased from BD BioSciences (San Jose, CA, USA). Akt 2 and $\beta$-actin were purchased from Novus (Littleton, CO, U.S.A.). Bad, phospho-p38 Thr180/ Tyr182, E2F-1, Cyclin A, Akt1, phospho-SGK Ser255/ Thr256, and phospho-mTOR Ser2448 antibodies were from Millipore (Billerica, MA, U.S.A.). TRIB3, Cdk7, and Cyclin $\mathrm{H}$ antibodies were from Abnova (Taipei, Taiwan). Chk1 and Chk2 antibodies were purchased from Abcam (Cambridge Science Park, Cambridge, UK). Blots were scanned and quantified using a LI-COR Odyssey near-infrared imaging system. Horseradish peroxidaseconjugated anti-rabbit and anti-mouse IgG secondary antibodies were purchased from Santa Cruz. $\alpha$-tubulin and $\beta$-actin were used as loading controls.

\section{Quantitative real-time polymerase chain reaction (qRT-PCR)}

Cell RNA was extracted from LNCaP 104-R1 cells treated with ethanol (control), $10 \mu \mathrm{M}, 20 \mu \mathrm{M}$ or $40 \mu \mathrm{M}$ CAPE for $48 \mathrm{~h}$ by RNeasy Mini kit. Cell pellet was lysed by Buffer RLT. The mRNA expression of Akt1, Akt2, cyclin D, c-Myc and Skp2 p45 were assayed using SYBR Green real-time PCR arrays. GAPDH was assayed as RNA content loading control in each array. The transcript level of selected genes was analyzed using the $\mathrm{RT}^{2}$ Profiler PCR Array Data Analysis website (http://www.sabiosciences. com/pcr/arrayanalysis.php) and normalized to GAPDH levels [26].

\section{Micro-western arrays}

LNCaP 104-R1 cells were treated with $0,10,20$, or $40 \mu \mathrm{M}$ CAPE for $96 \mathrm{~h}$. Three biological replicates of cells were lysed in SDS lysis buffer (240 mM Trisacetate, 1\% SDS, 1\% glycerol, 5 mM EDTA pH 8.0) with DTT, protease inhibitors, and a cocktail of phosphatase inhibitors. Micro-Western Arrays were performed to measure protein expression and phosphorylation status modification as previously described [22, 104]: Gel fabrication. Glass casting plates (one measuring $14 \times 27$ $\mathrm{cm}$, the other measuring $14 \times 28 \mathrm{~cm}$ ) were sprayed with BlueSlick (Serva) and wiped thoroughly. Rubber spacers were placed on three sides of the inner coated sides of the glass plate. One rectangle of Netfix (Serva) was placed on the glass plate on top of the spacers. The second glass plate was placed on top with the coated surface facing down. Twelve clamps were placed around the three gasketed edges of the sandwich. Gel reagents: For 10\% acrylamide gel, we gently mixed $6 \mathrm{ml}$ of $5 \times$ gel buffer (1.2 M Tris-Acetate, adjust pH of Tris-base (Sigma) with acetic acid (Fisher) to 6.9), $10 \mathrm{ml}$ acrylamide (Ultrapure)

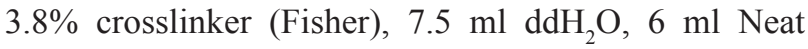
glycerol, $300 \mu 1$ 10\% w/v SDS, $150 \mu 1$ 10\% APS, and 12 $\mu$ Ultrapure TEMED (Invitrogen). This is enough for 2 gels. A $30 \mathrm{ml}$ syringe with a 19 gauge needle was used to 
inject the gel mixtures. The sandwich was laid horizontally for an hour. The gel was then removed from the bottom glass plate. Microarraying: The lysates were spotted using a noncontact microarrayer (GeSiM Nanoplotter 2.1E) with active humidification. Z-height measurements were taken before the print of each gel. The printing performance of each tip was validated with a stroboscope before beginning each microarray print. If printing was inconsistent, $200 \mu \mathrm{l}$ of $50 \%$ methanol- $50 \% \mathrm{HCl}$ was loaded into the tip and dispensed three times using manual mode. The tips were washed for $60 \mathrm{~s}$ using the wash/dry cycle and rechecked with the stroboscope. MWAs were printed onto either one or two gels per array run. Tip dispense height was held at $1.5 \mathrm{~mm}$ above the gel surface while printing. Samples were placed with the ladder in well A1 of a 384 well plate and samples consecutively in A2-A7. Software NP2.15.46 was used. The TransferTipMultiSim04H9 (GeSiM) was run using the transfer text and the workplate definition file provided in Supplementary Note 3 as reported previously $[22,104]$. Odyssey protein ladder (LI-COR) was printed in lane 1 at a 1:2 dilution in lysis buffer. After print completion, the gel was subsequently rehydrated for $5 \mathrm{~min}$ in the rehydration buffer described above with gentle agitation. After rehydration, the gel was placed onto the multiphor (GE Healthcare) for horizontal dry electrophoresis. Horizontal dry electrophoresis: Samples were separated by size using a multiphor (GE Healthcare). The power supply was set at $350 \mathrm{~V}, 30 \mathrm{~W}$ and unlimited amps. The lowest-molecular-weight ladder bands migrated about $9 \mathrm{~mm}$ (the length of one well of a 96-well plate) in $12 \mathrm{~min}$. Transfer: After electrophoresis, the gel was placed protein side down onto nitrocellulose (Bio-Rad) premoistened in transfer buffer ( $25 \mathrm{mM}$ Tris base, $0.2 \mathrm{M}$ glycine (Fisher), 20\% methanol (Sigma), pH 8.5). Filter paper was placed on either side of the nitrocellulose and gel, and was clamped in a transfer box cartridge. Bubbles were pressed out with a roller. The gels were transferred either at $0.8 \mathrm{~A}$ for $60 \mathrm{~min}$ or $0.15 \mathrm{~A}$ overnight at $4^{\circ} \mathrm{C}$ in a Criterion transfer box (Bio-Rad) with plate electrode. Blotting: Nitrocellulose was removed from the transfer apparatus and washed for 5 min in TBS (without Tween 20) to remove methanol. The blots were blocked for 1 $\mathrm{h}$ in Odyssey blocking buffer (LI-COR). The blot was aligned on the gasket by placing the visible ladder on the vertical lines and centering the ladder between the horizontal lines. The gasket was clamped into the 96-well isolation device, and primary antibodies were pipetted into the appropriate wells, making sure that the membrane remained wet during the process. The primary antibody was diluted in pure Odyssey blocking buffer (without Tween 20) overnight. We added $150 \mu \mathrm{l}$ of diluted antibody per well. After incubation, the wells were washed four times with $200 \mu \mathrm{l}$ of TBST per well using a multichannel pipettor. Goat anti-rabbit Alexa Fluor 680-conjugated secondary (Invitrogen), goat anti-rabbit and goat antimouse IR800-conjugated secondary antibodies $(1: 5,000)$
(LI-COR) were diluted in 20\% Odyssey blocking buffer, $80 \%$ TBS (without Tween 20). We added $150 \mu \mathrm{l}$ of the diluted secondary antibody to the appropriate well. After incubation for an hour, the blot was washed three times with $200 \mu \mathrm{l}$ TBST while clamped in the gasketing device (Arrayit). The blot was then removed from the gasket, placed in a box top and washed for an additional $5 \mathrm{~min}$ in TBST. For the fifth wash, TBS without Tween 20 was used, washing for $5 \mathrm{~min}$. The membrane was completely dried using pressurized air and scanned using the LI-COR Odyssey imager at $24 \mu \mathrm{m}$ resolution and high quality (using laser intensity $1.0 \mathrm{on}$ the $700 \mathrm{~nm}$ channel, and using laser intensity 2.0 on the 800 channel) settings. Analysis: Scanned images were saved for analysis as 16-bit tiff files. Genepix 8.0 (Molecular Devices) was used to record the mean by drawing an equally sized circle around the appropriately sized band for each sample. Appropriate size was defined as within $10 \mathrm{kDa}$ of the size as defined by the antibody product sheet as measured in comparison to the LI-COR ladder bands. All bands within this region that were visible were recorded. Bands outside this region were noted but the intensities were not recorded or analyzed. The background fluorescence was recorded by placing an equal sized circle in the blank space to the left of the first sample (not covering sample or ladder space) and the minimum value of this circle was recorded. Net intensity was calculated by subtracting each sample intensity from the background. To normalize sample concentration, the net intensities were divided by a simple mean of the net intensities for GAPDH, $\alpha$-tubulin and $\beta$-actin calculated separately for each array print. Fold change was calculated as the ratio of each normalized net intensity to the net intensity at the $0 \mathrm{~min}$ time point, minus one.

\section{Protein overexpression}

Ectopic expression of Akt1 and c-Myc was achieved by infecting LNCaP 104-R1 cells with $\mathrm{pSR} \alpha$ or $\mathrm{pBabe}$ retroviruses carrying the cDNA of the indicated proteins, respectively. Antibiotic-resistant (G418 and puromycin) colonies were expanded and screened for increased target protein expression by western blot analysis. For Skp2 overexpression, LNCaP 104-R1 cells were infected with pMV7 retrovirus containing Skp2 inserts that was generated in $\Phi \mathrm{NX}$-Ampho packaging cells using procedures described previously [14]. The $\Phi$ NX-Ampho packaging cell line was provided by Garry Nolan of Stanford University. Stably infected cells were selected by G418. Cells infected with retrovirus carrying empty vectors were used as controls.

\section{siRNA knockdown of p53, p27 ${ }^{\text {Kip1 }}$ and p21 ${ }^{\text {Cip1 }}$}

Human $\mathrm{p} 53$, p2 $7^{\mathrm{Kip} 1}, \mathrm{p} 21^{\mathrm{Cip} 1}$ antisense and randomly scrambled sequence control were purchased from GE Healthcare (Little Chalfont, United Kingdom). The 
transfection procedure was performed using lipofectamine RNAiMAX (Invitrogen, Carlsbad, CA, U.S.A.) according to the manufacturer's recommended protocol. $40 \mathrm{nM}$ RNA were used for scramble, p53, p2 $7^{\text {Kip } 1}$ and p21 ${ }^{\text {Cip1 }}$ knockdown.

\section{Cellular senescence assay}

$5 \times 10^{4}$ LNCaP 104R1 cells were seeded in each well of 6-well plate with DMEM containing $10 \%$ CS-FBS. $24 \mathrm{~h}$ after plating, cells were treated with increasing concentrations of CAPE. After an additional $96 \mathrm{~h}$, cells were washed with PBS and added $1 \mathrm{~mL}$ of Fixing Solution per well (Millpore, Billerica, MA, U.S.A.). Following 15 min room temperature incubation, the cells were washed twice with PBS and added $2 \mathrm{~mL}$ of senescence-associated betagalactosidase (SA- $\beta$-gal) Detection Solution. After incubating at $37^{\circ} \mathrm{C}$ without $\mathrm{CO}_{2}$ overnight, the cells were washed twice with PBS and photo image of the cells were taken with phase contrast microscopy or light microscopy.

\section{Xenografts in athymic mice}

Experiments involving mice were approved by National Health Research Institutes Institutional Animal Care and Use Committee (NHRI-IACUC-101115-A). The study was carried out in strict accordance with the recommendations in the Guide for the Care and Use of Laboratory Animals of the National Institutes of Health. Male Balb/c nu/nu mice purchased from National Laboratory Animal Center (Taipei city, Taiwan) at age 6-8 weeks of age were injected subcutaneously in both flanks with $5 \times 10^{5}$ LNCaP 104-R1 cells suspended in $0.5 \mathrm{ml}$ of Matrigel (BD Bioscience, Franklin Lakes, NJ, USA) and were injected subcutaneously into athymic mice to form tumors. After 14 weeks, the average tumor volume exceeded $150 \mathrm{~mm}^{3}$. The mice were then separated into control group and CAPE treatment group. Control group contained 6 mice and 8 tumors, while CAPE treatment group contained 6 mice and 9 tumors. CAPE $(10 \mathrm{mg} / \mathrm{kg} /$ day in sesame oil $)$ or vehicle (sesame oil) was administered by gavage starting from 14th week after cancer cell injection. Tumor volume and body weight of mice carrying 104-R1 xenografts was measured weekly using calipers and volume was calculated using the formula volume $=$ length $\times$ width $\times$ height $\times 0.52$ [62, 105-107]. Tumor samples for Western blotting assay analysis were prepared from tissue homogenized in $2 \times$ Laemmli buffer as previously described $[14,106]$.

\section{Combined treatment of CAPE with PI3K inhibitor LY294002 or BCl-2 inhibitor ABT737}

Proliferation of LNCaP 104-R1 cells treated with combination of CAPE with LY294002 or CAPE with ABT737 was determined by 96-well proliferation assay. The relative cell number under combined treatment was compared to that being treated with only CAPE, LY294002, or ABT737 alone. The effect of the combined treatment was determined by the ratio of expected cell number/observed cell number. For example, treatment of 104-R1 cells with $5 \mu \mathrm{M}$ of ABT737 decreased the cell number to $69.2 \%$ and treatment with 104-R1 cells with $5 \mu \mathrm{M}$ CAPE alone decreased the cell number to $75.6 \%$. The expected cell number of treatment combining $5 \mu \mathrm{M}$ of ABT737 with $5 \mu \mathrm{M}$ CAPE was $0.692 \times 0.756$ $=52.3 \%$. The actual observed cell number is $47.0 \%$. The ratio of expected cell number/observed cell number is $0.523 / 0.470=1.1$. Ratio larger than one represents synergy of growth inhibition as the combined treatment of two drugs suppressed more cells than either drug alone. If the observed cell number is less than the cell number being treated with any one of the drug alone, this indicates additive suppressive effect of the combination treatment of the two drugs. For example, treatment of 104-R1 cells with $2.5 \mu \mathrm{M}$ of LY294002 decreased the cell number to $91.2 \%$, while treatment with 104-R1 cells with $40 \mu \mathrm{M}$ CAPE decreased the cell number to $14.5 \%$. The combination of $2.5 \mu \mathrm{M}$ of LY294002 with $40 \mu \mathrm{M}$ CAPE decreased the cell number to $13.1 \%$, then we called the combination of 2.5 $\mu \mathrm{M}$ of LY294002 with $40 \mu \mathrm{M}$ CAPE exhibited additive suppressive effects on LNCaP 104-R1 cells.

\section{Public domain data}

Expression profile of Tp53 gene from Singh prostate datasets was detected by reporter probe $1974 \_$s at with Human Genome U95A-Av2 Array [108], which contains 50 normal prostate gland samples and 52 prostate carcinoma samples. Expression profile of Tp53 gene from Tomlins prostate datasets was detected by reporter probe IMAGE:24415 [109], which contains 21 normal prostate gland epithelial samples, $4 \mathrm{BPH}$ (benign prostatic hyperplasia), 12 PIN (prostatic intraepithelial neoplasia), and 30 prostate carcinoma samples. Data were downloaded from Oncomine (http://www.oncomine.com) without further processing.

\section{Data analysis}

Data are presented as the mean $+/-$ SD of at least three experiments or are representative of experiments repeated at least three times. Student's $t$-test (two-tailed, unpaired) was used to evaluate the statistical significance of results from the proliferation assay experiments. A Microsoft Excel add-in program ED50V10 was used for calculating half maximal effective concentration (EC50).

\section{CONCLUSION}

Our finding suggested that treatment with CAPE caused cell cycle arrest and growth inhibition in CRPC cells both in vitro and in vivo via inhibition of Skp2 and induction $\mathrm{p} 53$, $\mathrm{p} 21^{\mathrm{Cip} 1}$ and $\mathrm{p} 27^{\mathrm{Kip} 1}$. We believe that CAPE treatment may be a novel and useful therapy for patient with CRPC. 


\section{ACKNOWLEDGMENTS}

This study was supported by CS-103-PP-14 (National Health Research Institutes), CA-103-SP-01 (Ministry of Health and Welfare), as well as MOST 103-2325-B-400-001 and MOST 103-2321-B-400-016 (Ministry of Science and Technology) in Taiwan for CPC, MOST 103-2633-B-400-002 for HJK, as well as supported by the National Core Facility Program for Biotechnology from Taiwan (NSC 102-2319-B-400 -001). HPL was supported by MOST 103-2325-B-400-002 (Taiwan). The funders had no role in study design, data collection and analysis, decision to publish, or preparation of the manuscript. We thank the support from the MicroWestern Array and Cell sorting core facility of NHRI.

\section{REFERENCES}

1. Gronberg H. Prostate cancer epidemiology. Lancet. 2003; 361:859-64.

2. Chuu CP, Kokontis JM, Hiipakka RA, Fukuchi J, Lin HP, Lin CY, et al. Androgens as therapy for androgen receptorpositive castration-resistant prostate cancer. J Biomed Sci. $2011 ; 18: 63$.

3. Hellerstedt BA, Pienta KJ. The current state of hormonal therapy for prostate cancer. CA Cancer J Clin. 2002; 52:154-79.

4. Gilligan T, Kantoff PW. Chemotherapy for prostate cancer. Urology. 2002; 60:94-100; discussion 00.

5. Feldman BJ, Feldman D. The development of androgenindependent prostate cancer. Nat Rev Cancer. 2001; 1:34- 45.

6. Bubendorf L, Kononen J, Koivisto P, Schraml P, Moch H, Gasser TC, et al. Survey of gene amplifications during prostate cancer progression by high-throughout fluorescence in situ hybridization on tissue microarrays. Cancer Res. 1999; 59:803-6.

7. Linja MJ, Savinainen KJ, Saramaki OR, Tammela TL, Vessella RL, Visakorpi T. Amplification and overexpression of androgen receptor gene in hormone-refractory prostate cancer. Cancer Res. 2001; 61:3550-5.

8. Mohler JL, Gregory CW, Ford OH, 3rd, Kim D, Weaver CM, Petrusz P, et al. The androgen axis in recurrent prostate cancer. Clin Cancer Res. 2004; 10:440-8.

9. Stanbrough M, Bubley GJ, Ross K, Golub TR, Rubin MA, Penning TM, et al. Increased expression of genes converting adrenal androgens to testosterone in androgen-independent prostate cancer. Cancer Res. 2006; 66:2815-25.

10. Visakorpi T, Hyytinen E, Koivisto $\mathrm{P}$, Tanner M, Keinanen R, Palmberg C, et al. In vivo amplification of the androgen receptor gene and progression of human prostate cancer. Nat Genet. 1995; 9:401-6.

11. Chen CD, Welsbie DS, Tran C, Baek SH, Chen R, Vessella R, et al. Molecular determinants of resistance to antiandrogen therapy. Nat Med. 2004; 10:33-9.
12. Horoszewicz JS, Leong SS, Chu TM, Wajsman ZL, Friedman M, Papsidero L, et al. The LNCaP cell line-a new model for studies on human prostatic carcinoma. Prog Clin Biol Res. 1980; 37:115-32.

13. Kokontis J, Takakura K, Hay N, Liao S. Increased androgen receptor activity and altered c-myc expression in prostate cancer cells after long-term androgen deprivation. Cancer Res. 1994; 54:1566-73.

14. Kokontis JM, Hay N, Liao S. Progression of LNCaP prostate tumor cells during androgen deprivation: hormoneindependent growth, repression of proliferation by androgen, and role for p27Kip1 in androgen-induced cell cycle arrest. Mol Endocrinol. 1998; 12:941-53.

15. Mathew P. Prolonged control of progressive castrationresistant metastatic prostate cancer with testosterone replacement therapy: the case for a prospective trial. Ann Oncol. 2008; 19:395-6.

16. Szmulewitz R, Mohile S, Posadas E, Kunnavakkam R, Karrison $\mathrm{T}$, Manchen E, et al. A randomized phase 1 study of testosterone replacement for patients with lowrisk castration-resistant prostate cancer. Eur Urol. 2009; 56:97-103.

17. Natarajan K, Singh S, Burke TR Jr., Grunberger D, Aggarwal BB. Caffeic acid phenethyl ester is a potent and specific inhibitor of activation of nuclear transcription factor NF-kappa, B. Proc Natl Acad Sci U S A. 1996; 93:9090-5.

18. Lin HP, Jiang SS, Chuu CP. Caffeic acid phenethyl ester causes p21 induction, Akt signaling reduction, and growth inhibition in PC-3 human prostate cancer cells. PLoS One. 2012; 7:e31286.

19. Chuu CP, Lin HP, Ciaccio MF, Kokontis JM, Hause RJ, Jr., Hiipakka RA, et al. Caffeic acid phenethyl ester suppresses the proliferation of human prostate cancer cells through inhibition of p70S6K and Akt signaling networks. Cancer Prev Res (Phila). 2012; 5:788-97.

20. Lin HP, Lin CY, Liu CC, Su LC, Huo C, Kuo YY, et al. Caffeic acid phenethyl ester as a potential treatment for advanced prostate cancer targeting akt signaling. Int J Mol Sci. 2013; 14:5264-83.

21. Lin HP, Lin CY, Hsiao PH, Wang HD, Sheng Jiang S, Hsu $\mathrm{JM}$, et al. Difference in protein expression profile and chemotherapy drugs response of different progression stages of LNCaP sublines and other human prostate cancer cells. PLoS One. 2013; 8:e82625.

22. Ciaccio MF, Wagner JP, Chuu CP, Lauffenburger DA, Jones RB. Systems analysis of EGF receptor signaling dynamics with microwestern arrays. Nat Meth. 2010; $7: 148-55$.

23. Leontieva OV, Lenzo F, Demidenko ZN, Blagosklonny MV. Hyper-mitogenic drive coexists with mitotic incompetence in senescent cells. Cell Cycle. 2012; 11:4642-9.

24. Blagosklonny MV. Cell cycle arrest is not yet senescence, which is not just cell cycle arrest: terminology for TORdriven aging. Aging. 2012; 4:159-65. 
25. Blagosklonny MV. Hypoxia, MTOR and autophagy: converging on senescence or quiescence. Autophagy. 2013; 9:260-2.

26. Lin CY, Huo C, Kuo LK, Hiipakka RA, Jones RB, Lin HP, et al. Cholestane-3beta, 5alpha, 6beta-triol suppresses proliferation, migration, and invasion of human prostate cancer cells. PLoS One. 2013; 8:e65734.

27. Celli N, Dragani LK, Murzilli S, Pagliani T, Poggi A. In vitro and in vivo stability of caffeic acid phenethyl ester, a bioactive compound of propolis. J Agric Food Chem. 2007; 55:3398-407.

28. Wang X, Pang J, Maffucci JA, Pade DS, Newman RA, Kerwin SM, et al. Pharmacokinetics of caffeic acid phenethyl ester and its catechol-ring fluorinated derivative following intravenous administration to rats. Biopharm Drug Dispos. 2009; 30:221-8.

29. Kudugunti SK, Vad NM, Ekogbo E, Moridani MY. Efficacy of caffeic acid phenethyl ester (CAPE) in skin B16-F0 melanoma tumor bearing C57BL/6 mice. Invest New Drugs. 2011; 29:52-62.

30. Akyol S, Ginis Z, Armutcu F, Ozturk G, Yigitoglu MR, Akyol O. The potential usage of caffeic acid phenethyl ester (CAPE) against chemotherapy-induced and radiotherapyinduced toxicity. Cell Biochem Funct. 2012; 30:438-43.

31. Itahana K, Dimri G, Campisi J. Regulation of cellular senescence by p53. Eur J Biochem. 2001; 268:2784-91.

32. Campisi J, d'Adda di Fagagna F. Cellular senescence: when bad things happen to good cells. Nat Rev Mol Cell Biol. 2007; 8:729-40.

33. Zou L, Elledge SJ. Sensing DNA damage through ATRIP recognition of RPA-ssDNA complexes. Science. 2003; 300:1542-8.

34. Toledo LI, Murga M, Gutierrez-Martinez P, Soria R, Fernandez-Capetillo O. ATR signaling can drive cells into senescence in the absence of DNA breaks. Genes Dev. 2008; 22:297-302.

35. Chiao C, Carothers AM, Grunberger D, Solomon G, Preston GA, Barrett JC. Apoptosis and altered redox state induced by caffeic acid phenethyl ester (CAPE) in transformed rat fibroblast cells. Cancer Res. 1995; 55:3576-83.

36. Cimprich KA, Shin TB, Keith CT, Schreiber SL. cDNA cloning and gene mapping of a candidate human cell cycle checkpoint protein. Proc Natl Acad Sci U S A. 1996; 93:2850-5.

37. Brown EJ. The ATR-independent DNA replication checkpoint. Cell Cycle. 2003; 2:188-9.

38. Brown EJ, Baltimore D. Essential and dispensable roles of ATR in cell cycle arrest and genome maintenance. Genes Dev. 2003; 17:615-28.

39. Lee JH, Paull TT. Activation and regulation of ATM kinase activity in response to DNA double-strand breaks. Oncogene. 2007; 26:7741-8.
40. Bakkenist CJ, Kastan MB. DNA damage activates ATM through intermolecular autophosphorylation and dimer dissociation. Nature. 2003; 421:499-506.

41. Canman CE, Lim DS. The role of ATM in DNA damage responses and cancer. Oncogene. 1998; 17:3301-8.

42. Canman CE, Lim DS, Cimprich KA, Taya Y, Tamai K, Sakaguchi K, et al. Activation of the ATM kinase by ionizing radiation and phosphorylation of p53. Science. 1998; 281:1677-9.

43. Chen P, Luo C, Deng Y, Ryan K, Register J, Margosiak S, et al. The 1.7 A crystal structure of human cell cycle checkpoint kinase Chk1: implications for Chk1 regulation. Cell. 2000; 100:681-92.

44. Sanchez Y, Wong C, Thoma RS, Richman R, Wu Z, Piwnica-Worms H, et al. Conservation of the Chk1 checkpoint pathway in mammals: linkage of DNA damage to Cdk regulation through Cdc25. Science. 1997; 277:1497-501.

45. Zhang Y, Hunter T. Roles of Chk1 in cell biology and cancer therapy. Int J Cancer. 2014; 134:1013-23.

46. Patil M, Pabla N, Dong Z. Checkpoint kinase 1 in DNA damage response and cell cycle regulation. Cell Mol Life Sci. 2013; 70:4009-21.

47. Matsuoka S, Huang M, Elledge SJ. Linkage of ATM to cell cycle regulation by the Chk2 protein kinase. Science. 1998; 282:1893-7.

48. Chehab NH, Malikzay A, Appel M, Halazonetis TD. Chk2/ hCds1 functions as a DNA damage checkpoint in G(1) by stabilizing p53. Genes Dev. 2000; 14:278-88.

49. Wang Z, Gao D, Fukushima H, Inuzuka H, Liu P, Wan L, et al. Skp2: a novel potential therapeutic target for prostate cancer. Biochim Biophys Acta. 2012; 1825:11-7.

50. Reed SI. Ratchets and clocks: the cell cycle, ubiquitylation and protein turnover. Nat Rev Mol Cell Biol. 2003; 4:855-64.

51. Bashir T, Pagan JK, Busino L, Pagano M. Phosphorylation of Ser72 is dispensable for Skp2 assembly into an active SCF ubiquitin ligase and its subcellular localization. Cell Cycle. 2010; 9:971-4.

52. Boutonnet C, Tanguay PL, Julien C, Rodier G, Coulombe P, Meloche S. Phosphorylation of Ser72 does not regulate the ubiquitin ligase activity and subcellular localization of Skp2. Cell Cycle. 2010; 9:975-9.

53. Lu L, Schulz H, Wolf DA. The F-box protein SKP2 mediates androgen control of p27 stability in LNCaP human prostate cancer cells. BMC Cell Biol. 2002; 3:22.

54. Rodier G, Coulombe P, Tanguay PL, Boutonnet C, Meloche S. Phosphorylation of Skp2 regulated by CDK2 and $\mathrm{Cdc} 14 \mathrm{~B}$ protects it from degradation by $\mathrm{APC}(\mathrm{Cdh} 1)$ in G1 phase. EMBO J. 2008; 27:679-91.

55. Yang G, Ayala G, De Marzo A, Tian W, Frolov A, Wheeler TM, et al. Elevated Skp2 protein expression in human prostate cancer: association with loss of the 
cyclin-dependent kinase inhibitor p27 and PTEN and with reduced recurrence-free survival. Clin Cancer Res. 2002; $8: 3419-26$.

56. Nguyen PL, Lin DI, Lei J, Fiorentino M, Mueller E, Weinstein $\mathrm{MH}$, et al. The impact of Skp2 overexpression on recurrence-free survival following radical prostatectomy. Urol Oncol. 2011; 29:302-8.

57. Ben-Izhak O, Lahav-Baratz S, Meretyk S, Ben-Eliezer S, Sabo E, Dirnfeld M, et al. Inverse relationship between Skp2 ubiquitin ligase and the cyclin dependent kinase inhibitor p27Kip1 in prostate cancer. J Urol. 2003; 170:241-5.

58. Lin HK, Wang G, Chen Z, Teruya-Feldstein J, Liu Y, $\mathrm{Chan} \mathrm{CH}$, et al. Phosphorylation-dependent regulation of cytosolic localization and oncogenic function of Skp2 by Akt/PKB. Nat Cell Biol. 2009; 11:420-32.

59. Shim EH, Johnson L, Noh HL, Kim YJ, Sun H, Zeiss C, et al. Expression of the F-box protein SKP2 induces hyperplasia, dysplasia, and low-grade carcinoma in the mouse prostate. Cancer Res. 2003; 63:1583-8.

60. Lin HK, Chen Z, Wang G, Nardella C, Lee SW, Chan CH, et al. Skp2 targeting suppresses tumorigenesis by Arf-p53independent cellular senescence. Nature. 2010; 464:374-9.

61. van Duijn PW, Trapman J. PI3K/Akt signaling regulates p27(kip1) expression via Skp2 in PC3 and DU145 prostate cancer cells, but is not a major factor in p27(kip1) regulation in LNCaP and PC346 cells. Prostate. 2006; 66:749-60.

62. Chuu CP, Kokontis JM, Hiipakka RA, Fukuchi J, Lin HP, Lin CY, et al. Androgen suppresses proliferation of castrationresistant LNCaP 104-R2 prostate cancer cells through androgen receptor, Skp2, and c-Myc. Cancer Sci. 2011; 102:2022-8.

63. Yang G, Ayala G, De Marzo A, Tian W, Frolov A, Wheeler TM, et al. Elevated Skp2 protein expression in human prostate cancer: association with loss of the cyclindependent kinase inhibitor p27 and PTEN and with reduced recurrence-free survival. Clin Cancer Res. 2002; 8:3419-26.

64. Soucek T, Pusch O, Hengstschlager-Ottnad E, Adams PD, Hengstschlager M. Deregulated expression of E2F-1 induces cyclin A- and E-associated kinase activities independently from cell cycle position. Oncogene. 1997; 14:2251-7.

65. Morgan DO. Principles of CDK regulation. Nature. 1995; 374:131-4.

66. Fesquet D, Labbe JC, Derancourt J, Capony JP, Galas S, Girard F, et al. The MO15 gene encodes the catalytic subunit of a protein kinase that activates cdc2 and other cyclindependent kinases (CDKs) through phosphorylation of Thr161 and its homologues. EMBO J. 1993; 12:3111-21.

67. Gao D, Inuzuka H, Tseng A, Chin RY, Toker A, Wei W. Phosphorylation by Akt1 promotes cytoplasmic localization of Skp2 and impairs APCCdh1-mediated Skp2 destruction. Nat Cell Biol. 2009; 11:397-408.

68. Sheppard KE, McArthur GA. The cell-cycle regulator CDK4: an emerging therapeutic target in melanoma. Clin Cancer Res. 2013; 19:5320-8.
69. Sherr CJ. Cancer cell cycles. Science. 1996; 274:1672-7.

70. Cantley LC, Neel BG. New insights into tumor suppression: PTEN suppresses tumor formation by restraining the phosphoinositide 3-kinase/AKT pathway. Proc Natl Acad Sci U S A. 1999; 96:4240-5.

71. Sarker D, Reid AH, Yap TA, de Bono JS. Targeting the $\mathrm{PI} 3 \mathrm{~K} / \mathrm{AKT}$ pathway for the treatment of prostate cancer. Clin Cancer Res. 2009; 15:4799-805.

72. Bedolla R, Prihoda TJ, Kreisberg JI, Malik SN, Krishnegowda NK, Troyer DA, et al. Determining risk of biochemical recurrence in prostate cancer by immunohistochemical detection of PTEN expression and Akt activation. Clin Cancer Res. 2007; 13:3860-7.

73. Kreisberg JI, Malik SN, Prihoda TJ, Bedolla RG, Troyer DA, Kreisberg S, et al. Phosphorylation of Akt (Ser473) is an excellent predictor of poor clinical outcome in prostate cancer. Cancer Res. 2004; 64:5232-6.

74. Sircar K, Yoshimoto M, Monzon FA, Koumakpayi IH, Katz RL, Khanna A, et al. PTEN genomic deletion is associated with p-Akt and AR signalling in poorer outcome, hormone refractory prostate cancer. J Pathol. 2009; 218:505-13.

75. Wegiel B, Bjartell A, Culig Z, Persson JL. Interleukin-6 activates $\mathrm{PI} 3 \mathrm{~K} / \mathrm{Akt}$ pathway and regulates cyclin A1 to promote prostate cancer cell survival. Int J Cancer. 2008; 122:1521-9.

76. McCall P, Gemmell LK, Mukherjee R, Bartlett JM, Edwards $\mathrm{J}$. Phosphorylation of the androgen receptor is associated with reduced survival in hormone-refractory prostate cancer patients. Br J Cancer. 2008; 98:1094-101.

77. Shimizu Y, Segawa T, Inoue T, Shiraishi T, Yoshida T, Toda Y, et al. Increased Akt and phosphorylated Akt expression are associated with malignant biological features of prostate cancer in Japanese men. BJU Int. 2007; 100:685-90.

78. Ayala G, Thompson T, Yang G, Frolov A, Li R, Scardino P, et al. High levels of phosphorylated form of Akt-1 in prostate cancer and non-neoplastic prostate tissues are strong predictors of biochemical recurrence. Clin Cancer Res. 2004; 10:6572-8.

79. Coffer PJ, Jin J, Woodgett JR. Protein kinase B (c-Akt): a multifunctional mediator of phosphatidylinositol 3-kinase activation. Biochem J. 1998; 335:1-13.

80. Gonzalez E, McGraw TE. The Akt kinases: isoform specificity in metabolism and cancer. Cell Cycle. 2009; 8:2502-8.

81. Alessi DR, James SR, Downes CP, Holmes AB, Gaffney PR, Reese CB, et al. Characterization of a 3-phosphoinositidedependent protein kinase which phosphorylates and activates protein kinase Balpha. Curr Biol. 1997; 7:261-9.

82. Sarbassov DD, Guertin DA, Ali SM, Sabatini DM. Phosphorylation and regulation of Akt/PKB by the rictormTOR complex. Science. 2005; 307:1098-101.

83. Jacinto E, Facchinetti V, Liu D, Soto N, Wei S, Jung SY, et al. SIN1/MIP1 maintains rictor-mTOR complex integrity and regulates Akt phosphorylation and substrate specificity. Cell. 2006; 127:125-37. 
84. Hammarsten $\mathrm{P}$, Cipriano $\mathrm{M}$, Josefsson A, Stattin $\mathrm{P}$, Egevad L, Granfors T, et al. Phospho-Akt immunoreactivity in prostate cancer: relationship to disease severity and outcome, Ki67 and phosphorylated EGFR expression. PLoS One. 2012; 7:e47994.

85. Dai B, Kong YY, Ye DW, Ma CG, Zhou X, Yao XD. Activation of the mammalian target of rapamycin signalling pathway in prostate cancer and its association with patient clinicopathological characteristics. BJU Int. 2009; 104:1009-16.

86. Brown EJ, Albers MW, Shin TB, Ichikawa K, Keith CT, Lane WS, et al. A mammalian protein targeted by G1-arresting rapamycin-receptor complex. Nature. 1994; 369:756-8.

87. Sabatini DM, Erdjument-Bromage H, Lui M, Tempst P, Snyder SH. RAFT1: a mammalian protein that binds to FKBP12 in a rapamycin-dependent fashion and is homologous to yeast TORs. Cell. 1994; 78:35-43.

88. Peterson RT, Beal PA, Comb MJ, Schreiber SL. FKBP12rapamycin-associated protein (FRAP) autophosphorylates at serine 2481 under translationally repressive conditions. J Biol Chem. 2000; 275:7416-23.

89. Huang S, Houghton PJ. Targeting mTOR signaling for cancer therapy. Curr Opin Pharmacol. 2003; 3:371-7.

90. Chung J, Kuo CJ, Crabtree GR, Blenis J. Rapamycin-FKBP specifically blocks growth-dependent activation of and signaling by the $70 \mathrm{kd}$ S6 protein kinases. Cell. 1992; 69:1227-36.

91. Kuo CJ, Chung J, Fiorentino DF, Flanagan WM, Blenis J, Crabtree GR. Rapamycin selectively inhibits interleukin-2 activation of p70 S6 kinase. Nature. 1992; 358:70-3.

92. Dennis PB, Jaeschke A, Saitoh M, Fowler B, Kozma SC, Thomas G. Mammalian, TOR: a homeostatic ATP sensor. Science. 2001; 294:1102-5.

93. Gingras AC, Raught B, Sonenberg N. Regulation of translation initiation by FRAP/mTOR. Genes Dev. 2001; 15:807-26.

94. Du K, Herzig S, Kulkarni RN, Montminy M. TRB3: a tribbles homolog that inhibits $\mathrm{Akt} / \mathrm{PKB}$ activation by insulin in liver. Science. 2003; 300:1574-7.

95. Hegedus Z, Czibula A, Kiss-Toth E. Tribbles: a family of kinase-like proteins with potent signalling regulatory function. Cell Signal. 2007; 19:238-50.

96. Wu CL, Zukerberg LR, Ngwu C, Harlow E, Lees JA. In vivo association of E2F and DP family proteins. Mol Cell Biol. 1995; 15:2536-46.

97. Murphree AL, Benedict WF. Retinoblastoma: clues to human oncogenesis. Science. 1984; 223:1028-33.

98. Korenjak M, Brehm A. E2F-Rb complexes regulating transcription of genes important for differentiation and development. Curr Opin Genet Dev. 2005; 15:520-7.
99. Hahm ER, Singh SV. Honokiol causes G0-G1 phase cell cycle arrest in human prostate cancer cells in association with suppression of retinoblastoma protein level/phosphorylation and inhibition of E2F1 transcriptional activity. Mol Cancer Ther. 2007; 6:2686-95.

100. Raffo AJ, Perlman H, Chen MW, Day ML, Streitman JS, Buttyan R. Overexpression of bcl-2 protects prostate cancer cells from apoptosis in vitro and confers resistance to androgen depletion in vivo. Cancer Res. 1995; 55:4438-45.

101. Lin Y, Fukuchi J, Hiipakka RA, Kokontis JM, Xiang J. Up-regulation of $\mathrm{Bcl}-2$ is required for the progression of prostate cancer cells from an androgen-dependent to an androgen-independent growth stage. Cell Res. 2007; 17:531-6.

102. Kokontis JM, Hsu S, Chuu CP, Dang M, Fukuchi J, Hiipakka RA, et al. Role of androgen receptor in the progression of human prostate tumor cells to androgen independence and insensitivity. Prostate. 2005; 65:287-98.

103. Lin HP, Kuo LK, Chuu CP. Combined treatment of curcumin and small molecule inhibitors suppresses proliferation of A549 and H1299 human non-small-cell lung cancer cells. Phytother Res. 2011; 26:122-6.

104 . Liu J, Kuo WL, Seiwert TY, Lingen M, Ciaccio MF, Jones RB, et al. Effect of complementary pathway blockade on efficacy of combination enzastaurin and rapamycin. Head Neck. 2011; 33:1774-82.

105. Chuu CP, Chen RY, Kokontis JM, Hiipakka RA, Liao S. Suppression of androgen receptor signaling and prostate specific antigen expression by (-)-epigallocatechin-3-gallate in different progression stages of LNCaP prostate cancer cells. Cancer Lett. 2009; 275:86-92.

106. Chuu CP, Hiipakka RA, Fukuchi J, Kokontis JM, Liao S. Androgen causes growth suppression and reversion of androgen-independent prostate cancer xenografts to an androgen-stimulated phenotype in athymic mice. Cancer Res. 2005; 65:2082-4.

107. Chuu CP, Hiipakka RA, Kokontis JM, Fukuchi J, Chen RY, Liao S. Inhibition of tumor growth and progression of $\mathrm{LNCaP}$ prostate cancer cells in athymic mice by androgen and liver $\mathrm{X}$ receptor agonist. Cancer Res. 2006; 66:6482-6.

108. Singh D, Febbo PG, Ross K, Jackson DG, Manola J, Ladd C, et al. Gene expression correlates of clinical prostate cancer behavior. Cancer Cell. 2002; 1:203-9.

109. Tomlins SA, Mehra R, Rhodes DR, Cao X, Wang L, Dhanasekaran SM, et al. Integrative molecular concept modeling of prostate cancer progression. Nat Genet. 2007; 39:41-51. 